\title{
The late Eocene-early Miocene El Maitén Belt evolution: Magmatic response to the changing subduction zone geodynamics
}

\author{
Lucía Fernández Paz ${ }^{\text {a,b, , Sofía B. Iannelli }}{ }^{\text {a,b }}$, Andrés Echaurren ${ }^{\text {a,b }}$, Miguel Ramos ${ }^{\text {a,b }}$, \\ Florencia Bechis $^{\mathrm{c}}$, Vanesa D. Litvak ${ }^{\mathrm{a}, \mathrm{b}}$, Alfonso Encinas ${ }^{\mathrm{d}}$, Simone Kasemann ${ }^{\mathrm{e}}$, \\ Friedrich Lucassen ${ }^{\mathrm{e}}$, Andrés Folguera ${ }^{\mathrm{a}, \mathrm{b}}$ \\ ${ }^{\text {a }}$ Facultad de Ciencias Exactas y Naturales, Universidad de Buenos Aires, Buenos Aires, Argentina \\ b Instituto de Estudios Andinos "Don Pablo Groeber" (IDEAN), CONICET-Universidad de Buenos Aires, Buenos Aires, Argentina \\ ${ }^{c}$ Instituto de Investigaciones en Diversidad Cultural y Procesos de Cambio (IIDyPCa), CONICET-Universidad Nacional de Río Negro, San Carlos de Bariloche, Argentina \\ ${ }^{\mathrm{d}}$ Departamento de Ciencias de la Tierra, Universidad de Concepción, Concepción, Chile \\ ${ }^{\mathrm{e}}$ MARUM - Center for Marine Environmental Sciences and Faculty of Geosciences, University of Bremen, Bremen, Germany
}

\section{A R T I C L E I N F O}

\section{Keywords:}

Continental arc volcanism

Geochemistry

Isotopes

Subduction dynamics

Slab rollback

\begin{abstract}
A B S T R A C T
During Mid-Cenozoic times, voluminous and genetically heterogeneous volcanism took place across North Patagonia in response to a period of plate tectonic reorganization. One of these volcanic associations is represented by the El Maitén Belt, located to the east of the main Andes for over $\sim 300 \mathrm{~km}$. This volcanic belt reflects the evolution of a continental arc in an extensional setting with remarkable compositional variations between the late Eocene and the early Miocene. We present new field and isotopic data that, together with lithological, geochronological and geochemical data compilations, suggest significant changes in the nature and location of magmatic sources. This evolution may be summarized in three stages: i) incipient arc magmatism, with a tholeiitic basaltic-basaltic andesitic composition, which evolved to ii) a mature arc, characterized by calcalkaline andesitic-dacitic associations, and a final stage characterized by iii) a late Oligocene-early Miocene juvenile, tholeiitic basaltic volcanism, interpreted as the result of a westward arc migration and extension in the back-arc. Therefore, considering the mid-Cenozoic tectonic configuration given by the eastward subduction of the Farallon and Nazca plates, we evaluate slab dynamics within a petrological framework that can reproduce the geochemical-geochronological characteristics of this belt. In this sense, rollback of the Nazca plate is the most suitable scenario to explain the El Maitén Belt behavior during this protracted extensional regime of Andean evolution.
\end{abstract}

\section{Introduction}

The long-lived evolution of the Andean margin constitutes an ideal scenario for studying orogenic and magmatic processes in a continental arc setting and their link with the different geodynamic scenarios that control their behavior. In this sense, the tectonomagmatic processes operating in different Andean segments have been spatial and temporarily variable. This is evidenced along the Chilean-Argentinean margin by the uneven distribution of the Paleozoic to Cenozoic batholiths and volcanic-volcanoclastic belts, i.e., emplaced at a variable distance to the trench. Several examples can be found in the present configuration of this Andean segment, such as the Pampean flat-slab $\left(\sim 27-33.5^{\circ}\right.$ S; e.g., Ramos et al., 2002) or the asthenospheric window associated to the
Chile Ridge subduction at $\sim 47^{\circ} \mathrm{S}$ (e.g., Breitsprecher and Thorkelson, 2009), which represent current tectonic processes disrupting the continuity of the magmatic arc.

Several factors may change the expression of arc magmatism in Andean type margins, such as perturbations of the thermal state of the wedge, changes in slab velocity and dip angle, tectonic accretion/ erosion processes, or anomalous mantle flow, among others (e.g., Ducea et al., 2015; England and Katz, 2010; Grove et al., 2009; Karlstrom et al., 2014; Kay et al., 2005; Schellart, 2017; Syracuse and Abers, 2006). In any case, changes in the configuration of the subduction zone affect the location in which the basaltic to andesitic arc magmas are generated (e. g., $\sim 10-30 \mathrm{~km}$ wide, at $\sim 100-150 \mathrm{~km}$ from the trench; Grove et al., 2012; Stern, 2002), as well as the geochemical signature of this first

\footnotetext{
* Corresponding author. Facultad de Ciencias Exactas y Naturales, Universidad de Buenos Aires, Buenos Aires, Argentina.

E-mail address: luciafp@gl.fcen.uba.ar (L. Fernández Paz).
} 
arc-related melts (e.g., Pearce and Peate, 1995; Turner et al., 2015; Turner and Langmuir, 2015).

To study the response of magmatism to a changing geodynamic context, we focus on the evolution of a Cenozoic volcanic belt emplaced in northern Patagonia between $\sim 39^{\circ}$ and $43^{\circ} \mathrm{S}$ : the El Maitén Belt. It corresponds to a volcanic-volcanoclastic succession with interbedded sedimentary sequences that was deposited $\sim 300 \mathrm{~km}$ away from the present-day trench through episodic pulses between $\sim 37$ and $\sim 19 \mathrm{Ma}$ (Bechis et al., 2014; Fernández Paz et al., 2018; Rapela et al., 1988, 1983). Interestingly, the first period of this volcanic activity marks the resumption of arc magmatism in the North Patagonian Andes after a protracted period of waning, when the eruption of within-plate volcanism dominated the magmatic activity (Aragón et al., 2011b; Fernández Paz et al., 2018). Moreover, the El Maitén Belt possesses particular compositional features that depict different paths in its magmatic evolution: an older magmatic stage of increasing arc maturity between $\sim 37$ and $33 \mathrm{Ma}$, and a younger one $(\sim 33-19 \mathrm{Ma})$ with a juvenile signature, emplaced during an extensional regime (Fernández Paz et al., 2019, 2018). We present an integrative overview of the magmatic evolution of the El Maitén Belt, on the base of previous geochemical-isotopic data compilations, new field and isotopic data of this unit, and a comparison with regionally distributed contemporaneous magmatic rocks (Aragón et al., 2011a; Fernández Paz et al., 2019, 2018; Iannelli et al., 2020, 2017; Kay et al., 2007; Rapela et al., 1988). The most relevant topics on the genesis of the El Maitén magmatism involve changes in the composition of the magma source, melting mechanisms, differentiation processes, and the interaction with the upper plate, as evidenced by the changes in its geochemical signature in relation to potential tectonic controls.

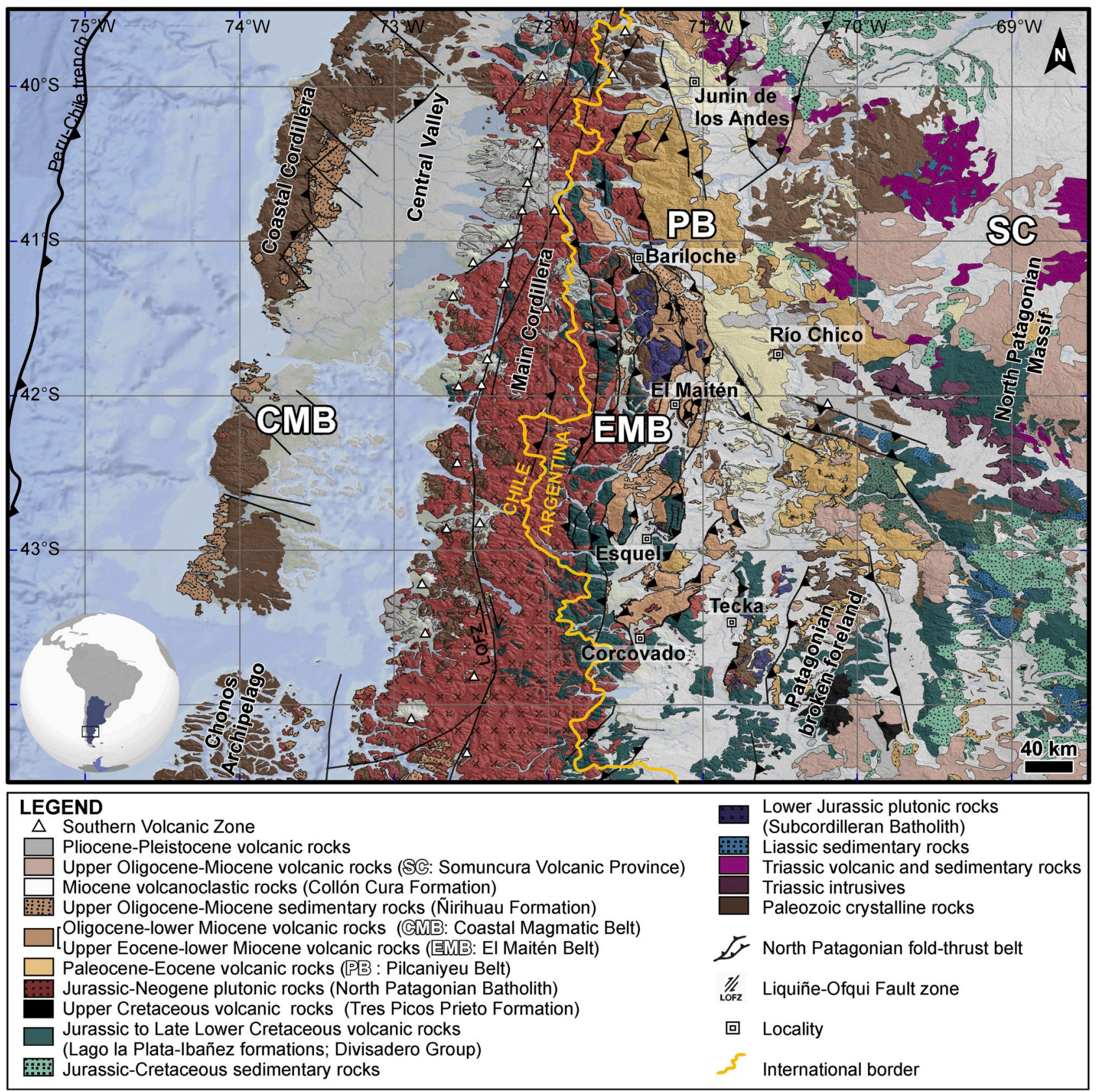

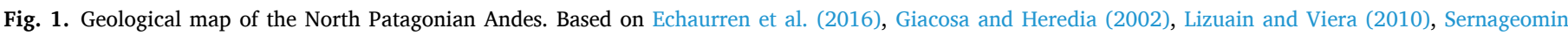

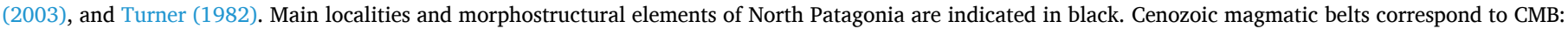
Coastal Magmatic Belt; EMB: El Maitén Belt; PB: Pilcaniyeu Belt; SC: Somuncura volcanic province. 


\section{Geological setting}

\subsection{Regional magmatism}

A vast record of igneous units crops out along and across the different morphostructural elements that compose the North Patagonian margin at the studied latitudes $\left(\sim 39^{\circ}\right.$ and $\left.43^{\circ} \mathrm{S}\right)$, from west to east: the Coastal Cordillera, the Central Valley, the North Patagonian Andes, the broken foreland area and the North Patagonian Massif (Fig. 1). Late Triassic igneous rocks are represented by the NNW-trending Batholith of Central Patagonia (Rapela et al., 1991), which extends south of the North Patagonian Massif about 1000-1100 km away of the Pacific paleotrench (Fig. 1). This magmatic belt was associated with arc magmatism in an extensional-transtensional regime (Rapela and Pankhurst, 1996, 1992; Zaffarana et al., 2014; and references therein). However, a recent study characterized this plutonic belt as a magmatic arc with an adakitic signature, whose emplacement would have been controlled by a shallow dipping slab arrangement, coevally with the development of contractional deformation (Navarrete et al., 2019).

After a period of quiescence of arc magmatism (of about $~ 14 \mathrm{My}$ ), arc activity resumed during the early Jurassic, coeval to the break-up of Gondwana and the outburst of the Karoo-Ferrar Igneous Province (Rapela et al., 2005). This arc plutonism, known as the Subcordilleran Batholith, took place to the west, in a closer position regarding the paleo-trench, and is composed of I-type, calc-alkaline subduction-related granitoids with minor amounts of gabbroic rocks (Gordon and Ort, 1993; Rapela et al., 2005, Fig. 1). By this time, the arc and retroarc regions experienced regional subsidence and the formation of extensional basins with the development of marine (paleo Pacific) Liassic sedimentary sequences (Fig. 1) (Lizuain, 1980; Nakayama, 1973). The locus of arc magmatism experienced a progressive migration toward the west during the Jurassic-Cretaceous, giving rise to the initial suites of the North Patagonian batholith in the western Andean slope, and its intermediate to acidic calc-alkaline volcanic equivalents, the Lago la Plata-Ibañez Formations and the Divisadero Group (Fig. 1) (Echaurren et al., 2017; Pankhurst et al., 1999). This westward arc migration has been interpreted as a product of a steepening and rollback of the slab (Echaurren et al., 2017; Navarrete et al., 2019; Rapela et al., 2005).

A change to compressional tectonics occurred during the midCretaceous, promoting the initial development of the North Patagonian fold-thrust belt, at the same time as the eastward expansion of the North Patagonian Batholith and calc-alkaline arc-related correlative volcanic units (Echaurren et al., 2017; Zaffarana et al., 2019). The eastward migration of the magmatic locus, together with regional correlations of crustal deformation and basin inversion processes, has been interpreted as the development of a large ( $\sim 1500 \mathrm{~km}$ along strike) flat-slab configuration (Gianni et al., 2018). Contrastingly, a late Cretaceous transitional arc to intraplate magmatism crops out to the south (Tres Picos Prieto Formation and equivalents) (Fig. 1), whose distinct geochemical behavior was associated with the contribution of subslab asthenospheric magmas, controlled by a slab-tearing in response to a differential steepening of the slab (Zaffarana et al., 2019).

A waning in the magmatic arc activity is recognized in the North Patagonian Batholith during the Paleogene (Pankhurst et al., 1999), coeval to the profuse magmatism developed in the Coastal Cordillera, as the Coastal Magmatic Belt, and to the east, in the eastern slope of the North Patagonian Andes and the broken foreland area, including the "Andesitic Series" (the Pilcaniyeu Belt and the El Maitén Belt; nomenclature details in section 2.1) and the Somuncura volcanic province far to the east in the North Patagonian Massif (Aragón et al., 2011b; Iannelli et al., 2017; Kay et al., 2007; Muñoz et al., 2000; Rapela et al., 1988; among others). The oldest volcanic sequences crop out in the broken foreland area, included in the Paleocene-middle Eocene Pilcaniyeu Belt ( 57.8-42 Ma; Figs. 1-3), which comprises a bimodal volcanic-volcanoclastic sequence with within-plate affinity. This belt is presumably associated with the opening of a slab window during the subduction of the Aluk-Farallon mid-ocean ridge (Aragón et al., 2013, 2011b; Iannelli et al., 2017; Rapela et al., 1988). This magmatism is followed by the late Eocene-early Miocene El Maitén Belt ( 37-19 Ma), the focus of this work, located to the west of the Pilcaniyeu Belt (Figs. 1-3; Bechis et al., 2014; Fernández Paz et al., 2018, 2019; Rapela et al., 1983, 1988). This belt comprises thick volcanic sequences, mainly of andesitic composition, characterized by an arc-related signature (Fernández Paz et al., 2018, 2019; Rapela et al., 1988). Both volcanic belts developed under an extensional regime, evidenced by the presence of wedge-like geometries associated with inverted normal faults that controlled their emplacement (Echaurren et al., 2016). Moreover, the younger pulses of the El Maitén Belt are associated with marine deposits, interpreted as a regional event where subsidence took place during a fast subsiding regime (Bechis et al., 2014; Encinas et al., 2016). Partially coeval to the El Maitén Belt, the magmatism of the Coastal Magmatic Belt and the Traiguén Formation took place to the west in the Coastal Cordillera and Chonos Archipelago (Fig. 1), being characterized by an arc-like signature, though some rocks display an alkaline-transitional imprint (Encinas et al., 2016; Henríquez Ascencio, 2016; López-Escobar and Vergara, 1997; Muñoz et al., 2000; Silva, 2003). At the same time, toward the east in the North Patagonian Massif, the broad intraplate mafic volcanism of the Somuncura province ( 29-16 Ma) may have been related to a short-lived asthenospheric upwelling (De Ignacio et al., 2001; Kay et al., 2007) (Fig. 1).

By the middle Miocene, the extensional conditions that controlled the deposition of the basal section of the Nirihuau Formation ended ( $\sim 22-11 \mathrm{Ma})$, whereas its middle and upper terms, together with the Collón Curá Formation ( 16-10 Ma), represent synorogenic deposits linked to a compressional tectonic phase ( 18-11 Ma; Bechis et al., 2014; Echaurren et al., 2016; Orts et al., 2012; Ramos et al., 2015). The North Patagonian Batholith renewed its magmatic activity during the late Miocene-Pliocene in the western slope of the Andes and Chonos Archipelago (Fig. 1), characterized by a more juvenile signature in poorly differentiated gabbroic suites (Pankhurst et al., 1999). However, plutonism is also registered to the east, in the foreland zone, which was accompanied by deformation, uplift, and the eastward migration of the foreland basins (Orts et al., 2012). This event was presumably interpreted as another shallow subduction event in the area (Orts et al., 2015) that ended with a steepening and the development of Pliocene-Pleistocene within plate magmatism in the retroarc zone (Haller et al., 2009; Massaferro et al., 2006; Mena et al., 2006; Pécskay et al., 2007). Finally, recent arc volcanism is developed in the main Andes, in a strong relationship with the Liquiñe-Ofqui fault zone that controls its emplacement (Cembrano and Lara, 2009; Lopez-Escobar et al., 1993).

\subsection{The Andesitic Series}

Variable stratigraphic schemes have been proposed over time to classify early to mid-Cenozoic volcanic sequences, given the widespread distribution, great lithological and compositional variability, and the uncertainties regarding the age of the volcanic pulses. Paleogene volcanic rocks in North Patagonia were first described near Bariloche city and grouped under the denomination of Andesitic Series (Feruglio, 1941, 1927; Groeber, 1918) (Fig. 2a). The Andesitic Series were initially characterized as volcano-sedimentary sequences composed of andesites, volcanic breccias, and tuffs, intercalated with epiclastic marine deposits (Feruglio, 1941; González Bonorino, 1973). Later, this volcanism was widely described along the North Patagonian Andes in studies of regional scopes, such as those focused on Cenozoic stratigraphy, the Nirihuau-Norquinco-Cushamen basins, and the marine transgressions that flooded North Patagonia during Cenozoic times (Cazau, 1972; Dessantí, 1972; Ramos, 1982; Uliana, 1978).

The Andesitic Series were first grouped in two volcanic belts, the Andean series to the west $\left(\sim 71^{\circ} \mathrm{W}\right)$, in the eastern slope of the North 

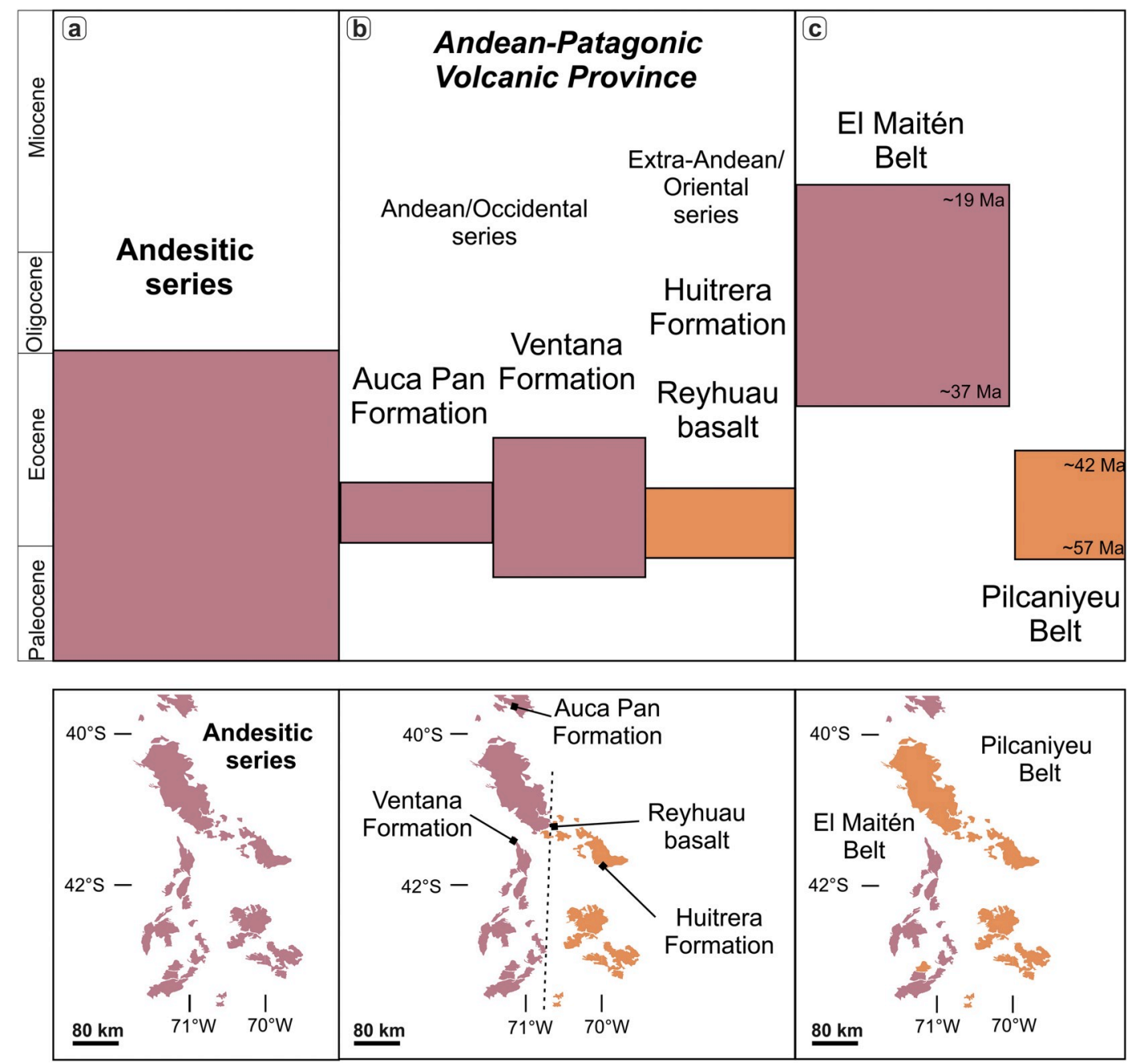

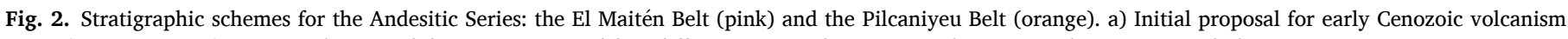

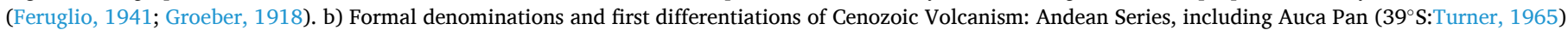

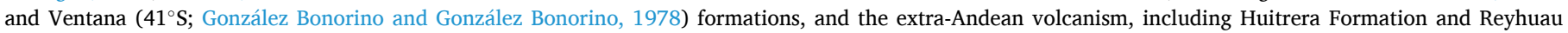

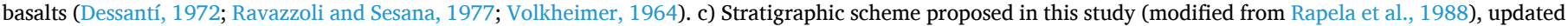

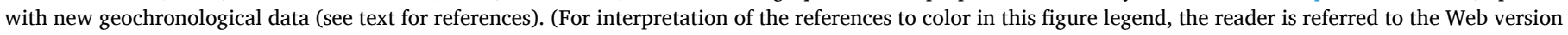
of this article.)

Patagonian Andes, and the extra-Andean series to the east $\left(\sim 70^{\circ} \mathrm{W}\right)$, in the broken foreland area (Volkheimer, 1964) (Fig. 2b). As part of the Andean series, the volcanic sequences that crop out near Bariloche city, and particularly in the Ventana hill $\left(\sim 41^{\circ} \mathrm{S} ; 71^{\circ} \mathrm{W}\right)$, were formally included in the Ventana Formation (González Bonorino, 1973; González Bonorino and González Bonorino, 1978), characterized by volcanic breccias and lava flows (basalts, andesites and minor dacites and rhyolites), interbedded with marine deposits. To the north $\left(\sim 39^{\circ} ; 71^{\circ} \mathrm{W}\right)$, Paleogene volcanic sequences of the Andean Series were grouped in the Auca Pan Formation (Turner, 1965), which is mainly characterized by basaltic to andesitic and subordinate dacitic to rhyolitic lavas (Dalla Salla et al., 1981). Both, the Ventana and the Auca Pan formations were formally distinguished from the Huitrera Formation, which encompasses eastern outcrops in the broken foreland zone (Ravazzoli and Sesana, 1977). The Huitrera Formation was fist described as bimodal volcanic associations, which crop out near Río Chico locality $\left(\sim 42^{\circ}\right.$; $\sim 70^{\circ} 30^{\prime} \mathrm{W}$; Figs. $2 \mathrm{~b}$ and 3 ) in the broken foreland area (Coira, 1979; Nullo, 1978; Volkheimer, 1964). Rapela et al. (1984, 1983) detailed the distribution, lithology, age and geochemical features of the Andean or Occidental Series (including Auca Pan and Ventana Formations) and the extra-Andean or Oriental Series (including Huitrera Formation and Reyhuau basalts), assigning the Andean series to the upper
Paleocene-Eocene and the extra-Andean series to the Paleocene (Fig. 2b). However, the restricted continuity between the volcanic outcrops and the close spatial association between both belts led to a misleading Paleocene-lower Eocene age assignation for the Andean series or Ventana Formation (see González Bonorino, 1973; González Bonorino and González Bonorino, 1978; González Díaz, 1979).

Finally, the integrated study of Rapela et al. (1988), based on field mapping, lithological studies, and an enhanced geochronological and geochemical database, presented a more accurately stratigraphic scheme for the volcanic rocks included in the Andesitic Series. This scheme separates the Andesitic series in the two volcanic belts, as we know them today, the Pilcaniyeu and the El Maitén Belt (Fig. 2c). The Pilcaniyeu Belt comprises the Paleocene to Eocene bimodal volcanic sequences of the Huitrera Formation and the Reyhuau basalts, which developed as a NW-trending belt from the eastern slope of the North Patagonian Andes $\left(40^{\circ} \mathrm{S}, 71^{\circ} \mathrm{W}\right)$ to the broken foreland zone $\left(42^{\circ} \mathrm{S}\right.$, $72^{\circ} \mathrm{W}$ ), and then continuing to the south. On the other hand, the El Maitén belt encompasses mainly andesitic to dacitic volcanic sequences that crop out in the eastern slope of the North Patagonian Andes, included in the Ventana and Auca Pan formations, which yielded mainly Oligocene K-Ar ages.

In this work we maintain the stratigraphic scheme defined by Rapela 


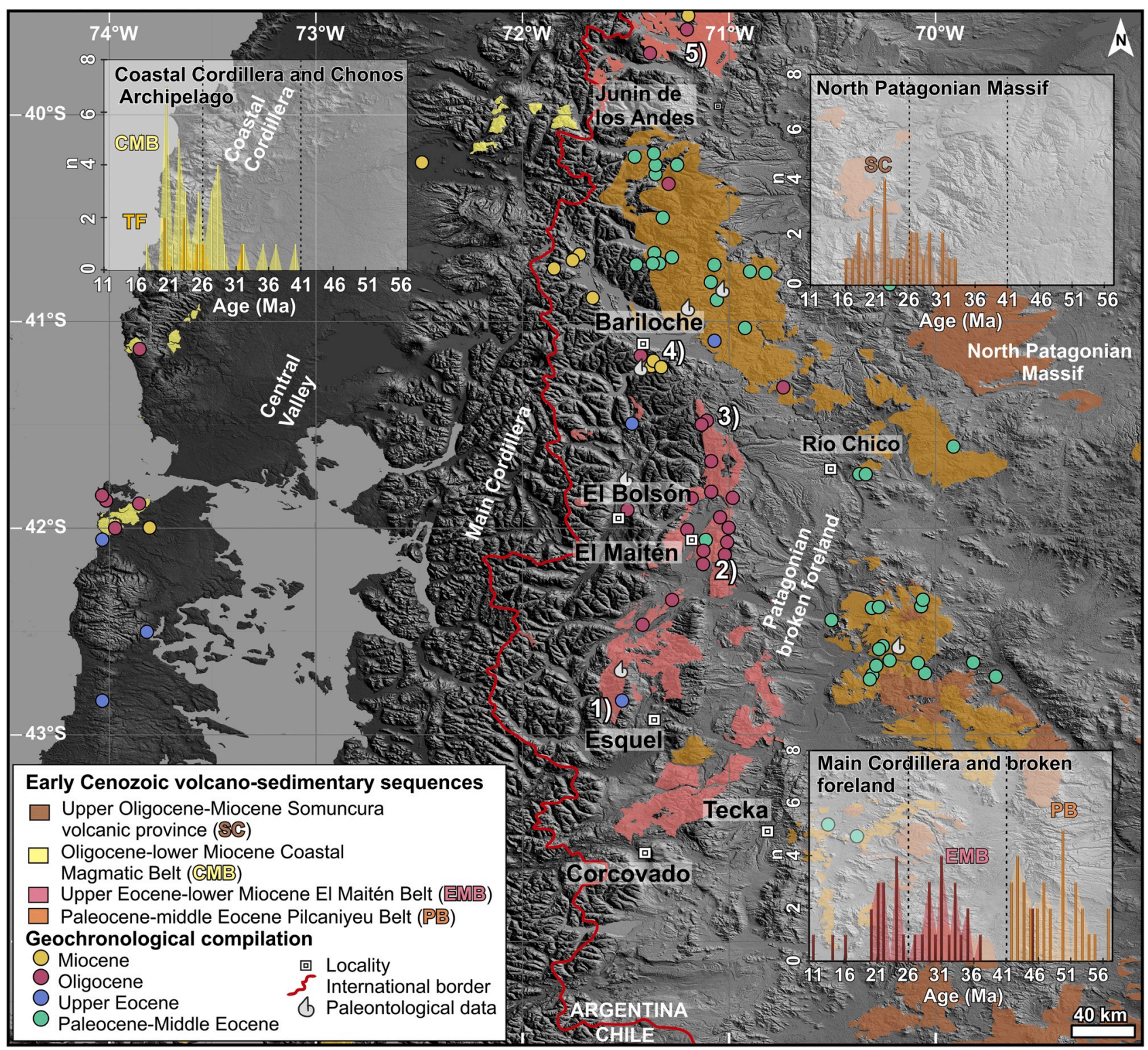

Fig. 3. Map of the early to mid-Cenozoic volcanic units cropping out in North Patagonia, and the distribution of the available geochronological and paleontological data on this volcanism. The three histograms depict the lifespan of each volcanic unit in the Costal Cordillera and Chonos Archipelago, in the main cordillera and the broken foreland, and in the North Patagonian Massif respectively (main morphostructural elements of North Patagonia are indicated in white). Rocks that crop out to the west in the Coastal Cordillera are included in the Coastal Magmatic Belt (CMB; 40-17 Ma), whereas volcanic rocks of the Traiguén Formation (TF; 26-20 Ma) crop out further south in the Chonos Archipelago (not shown, see location in Fig. 1). The most frequent ages of the both units are in the 29-20 Ma interval, with minor ages between 40 and $32 \mathrm{Ma}$. In the eastern slope of the Main Cordillera, the volcanic rocks of the El Maitén Belt (EMB) yield ages ranging from 37 to $19 \mathrm{Ma}$, and further east in the broken foreland area, Pilcaniyeu Belt (PB) outcrops were dated in 57-42 Ma. Magmatism in the North Patagonian Massif yielded ages between 33 and 15 Ma for the Somuncura volcanic province (SC). Ages are from Aragón et al. (2011a), Bechis et al. (2014), Benedini et al. (2017), Cazau et al. (1989), Encinas et al. (2016), Fernández Paz et al. (2018, 2019), Giacosa and Heredia (2002), Hervé et al. (1995), Iannelli et al. (2017), Kay et al. (2004, 2007), Lizuain and Viera (2010), Mazzoni et al. (1991), Muñoz et al. (2000), Ramos et al. (2014), Rapela et al. (1983, 1988), Remesal et al. (2012), and Turner (1982). Numbers 1) to 5) represent the location of the schematic sections of Fig. 4.

et al. (1988), which was updated with new age determinations that constrain the life-span of the Pilcaniyeu Belt from 58 to 42 Ma (Aragón et al., 2011b; Iannelli et al., 2017; Mazzoni et al., 1991; Wilf et al., 2010, 2005, 2003; and references therein) and the El Maitén Belt from 37 to 19 Ma (Bechis et al., 2014; Benedini et al., 2017; Fernández Paz et al., 2019, 2018) (Fig. 2c). It is worth to highlight the existence of other nomenclature for these volcanic belts, such as the eastern late Paleocene-Eocene belt (EPEB) for the Pilcaniyeu Belt, and Western Oligocene belt (WOB) for the El Maitén Belt (Aragón et al., 2019, 2013, 2011b). However, we prefer Rapela et al. (1988) scheme to avoid the use of an age-dependent nomenclature for the volcanic series.
3. Field data, age, and lithological features of the El Maitén Belt

\subsection{Age and distribution of El Maitén belt volcanic episodes}

The El Maitén Belt is a N-trending magmatic belt that crops out from $\sim 40^{\circ} 30^{\prime} \mathrm{S}$, around Bariloche city, to $\sim 43^{\circ} 30^{\prime}$, near Corcovado city (Figs. 1 and 3). Radiometric dating estimated the lifetime of this magmatic activity between the late Eocene and the early Miocene $(\sim 37$ 19 Ma; Bechis et al., 2014; Cazau et al., 1989; Fernández Paz et al., 2019, 2018; Rapela et al., 1988). Eocene volcanic rocks were recognized only in two localities, where U-Pb ages of 37 and 35.8 Ma were reported: 1) 


\begin{tabular}{|c|c|}
\hline \multicolumn{2}{|c|}{ Legend } \\
\hline $\bar{v}$ & Basaltic lava flows + tuffs \\
\hline & $\begin{array}{l}\text { Basaltic lava flows }+ \\
\text { sedimentary deposits }\end{array}$ \\
\hline V & Basaltic lava flows \\
\hline$-V$ & $\begin{array}{l}\text { Basaltic andesites and } \\
\text { andesitic lava flows + tuffs }\end{array}$ \\
\hline & $\begin{array}{l}\text { Basaltic andesites and andesitic lava } \\
\text { flows }+ \text { tuffs }+ \text { sedimentary deposits }\end{array}$ \\
\hline & $\begin{array}{l}\text { Basaltic andesites and andesitic lava } \\
\text { flows }\end{array}$ \\
\hline 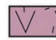 & Andesitic to dacitic lava flows \\
\hline V & Andesitic to dacitic lava flows + tuffs \\
\hline & Rhyolites \\
\hline E' & Tuffs \\
\hline 1 & Sedimentary deposits \\
\hline 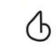 & Paleontological data \\
\hline$\star$ & Geochronological data \\
\hline $\mathrm{O}$ & Geochemical data \\
\hline
\end{tabular}

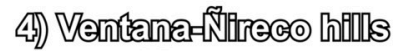 Miocene}

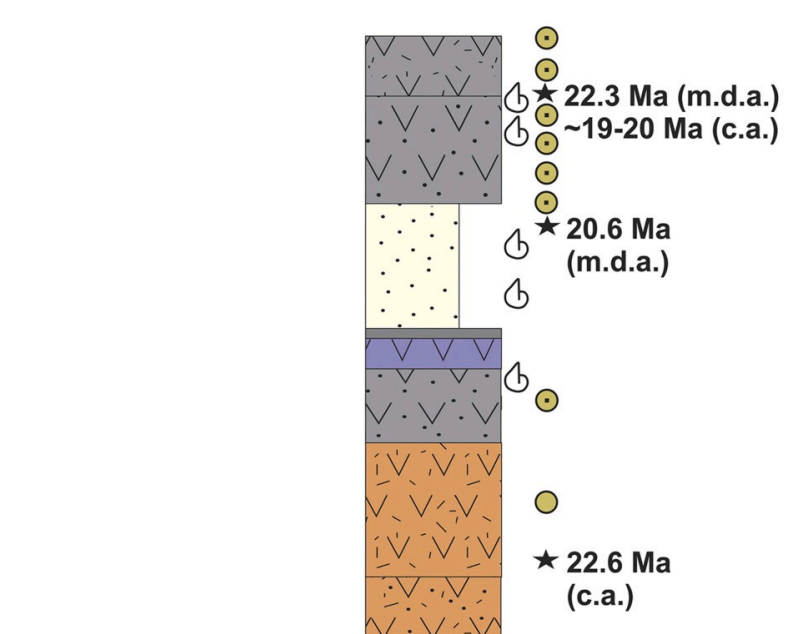

3) Las Bayas Oligocene

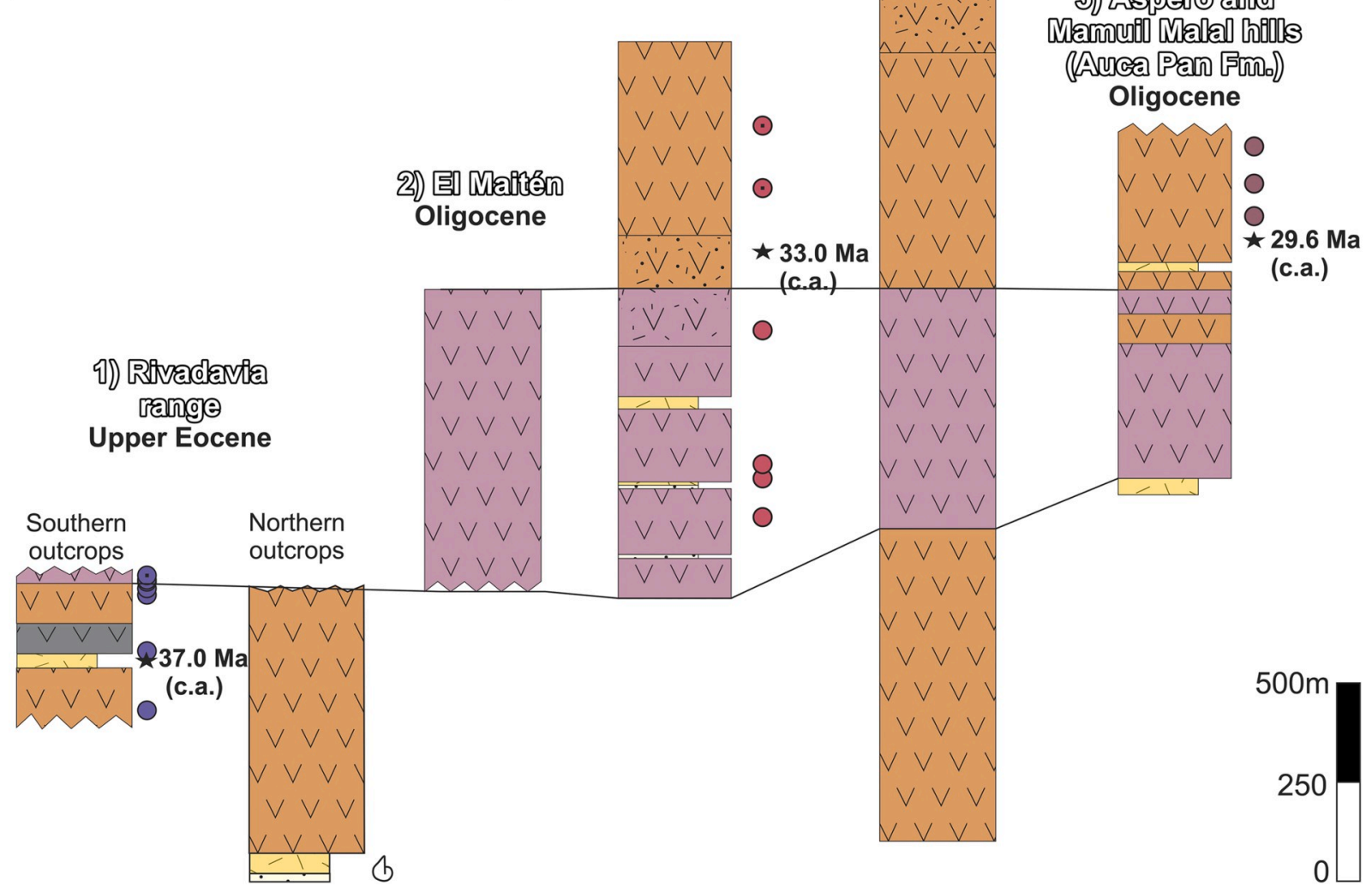

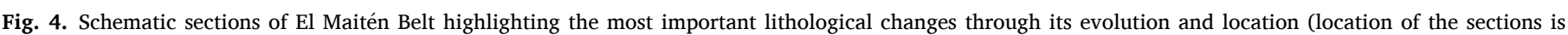

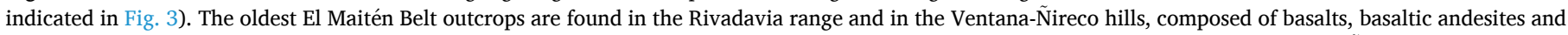

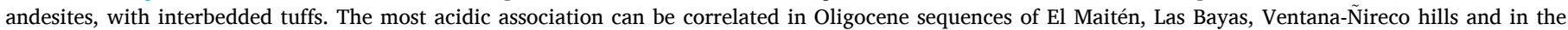

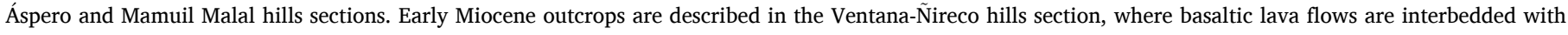

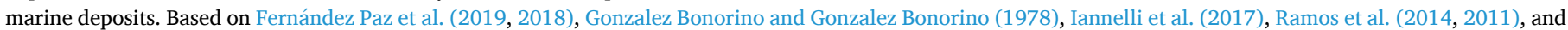

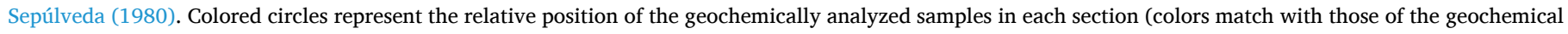
diagrams, Figs. 6-11). (For interpretation of the references to color in this figure legend, the reader is referred to the Web version of this article.)

the volcano-sedimentary sequences of Rivadavia range in the southern extreme of the belt (Fernández Paz et al., 2018) (Figs. 1 and 3), and to the north, in the El Bolsón depocenter (Benedini et al., 2017). Palynological evidence also supports Eocene ages for the initial stages of the El Maitén Belt. Middle Eocene fungal remains and spores have been identified in the bituminous shales that are interbedded between volcanic rocks at the base of the El Maitén Belt in the Rivadavia range (Sepúlveda, 1980). Despite the limited record of Eocene volcanic rocks, $\mathrm{U}-\mathrm{Pb}$ ages on detrital zircons of the Nirihuau Formation show late Eocene ages, whose provenance was assigned to the El Maitén belt (e.g., Butler et al., 2020). In this context, there are still uncertainties about the real extent of Eocene volcanism. 
Contrastingly with the restricted Eocene record, Oligocene ages are the most frequent along the belt. Oligocene volcanic rocks crop out more to the east (Fig. 3), distributed along the north of Esquel, El Maitén, El Bolsón, Bariloche and Junín de los Andes localities (Fernández Paz et al., 2019; Giacosa and Heredia, 2002; Rapela et al., 1988). Oligocene ages of the Ventana Formation range from 33 to $24 \mathrm{Ma}$, though they are concentrated mostly in the 33-30 Ma interval (Fig. 3). North of $40^{\circ} \mathrm{S}$, volcanic sequences of the Auca Pan Formation yield ages from 33.2 to 25 Ma (Franzese et al., 2011; Ramos et al., 2014; Rapela et al., 1988; Turner, 1973).

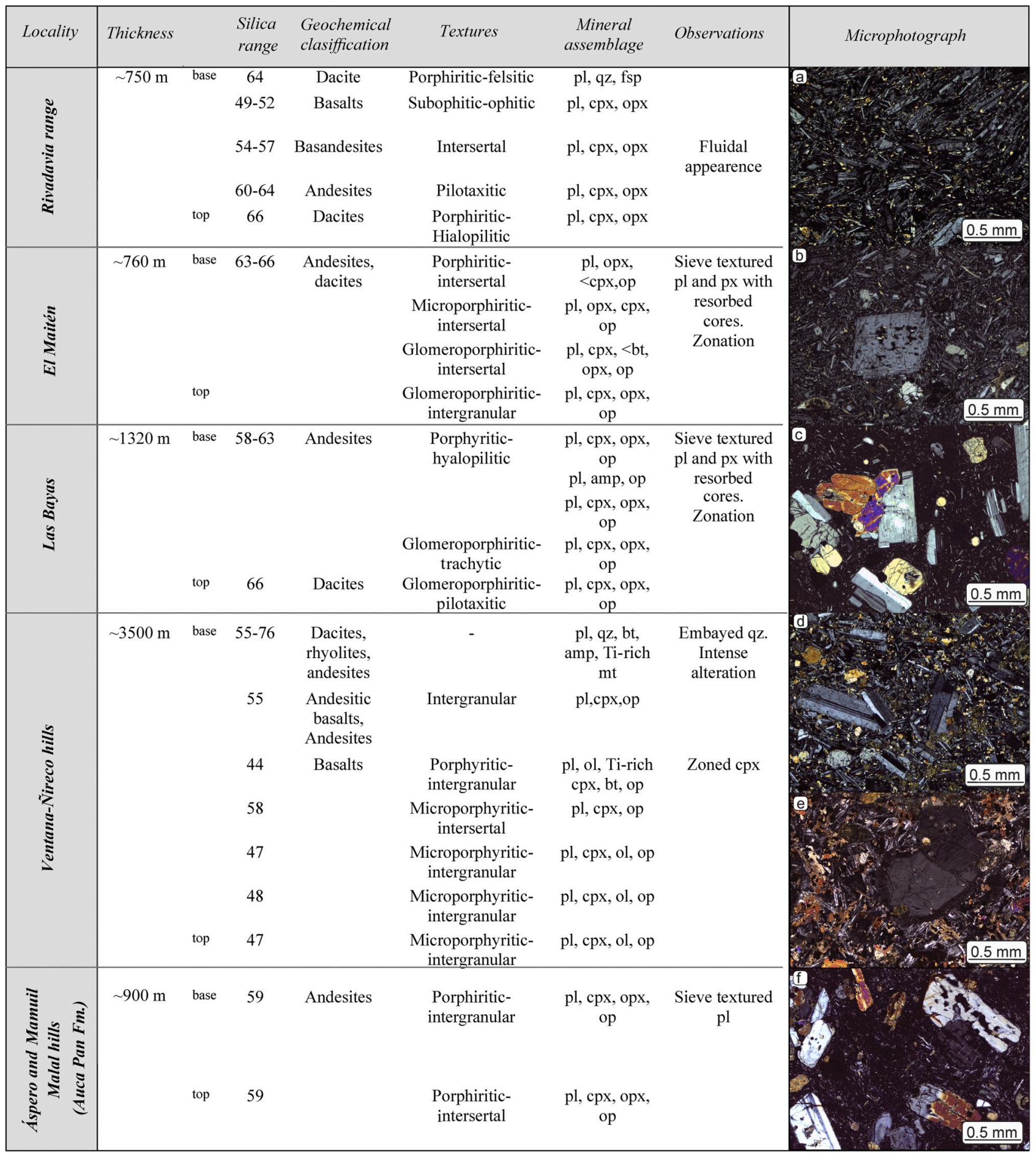

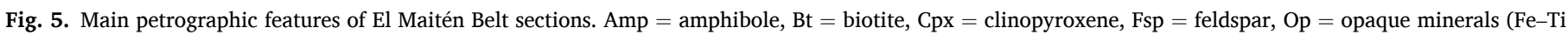

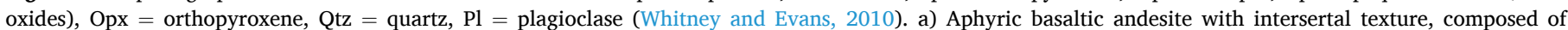

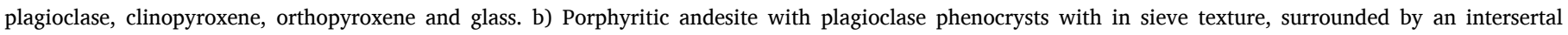

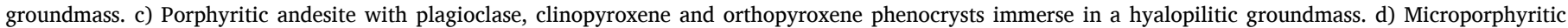

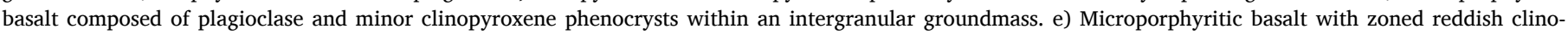

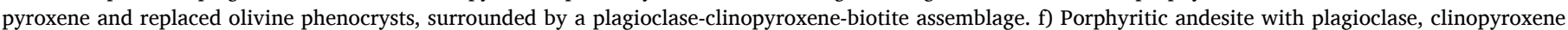

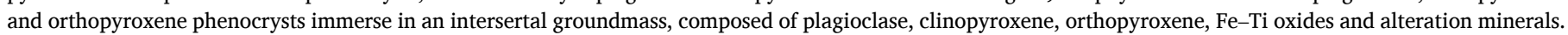


Miocene ages are restricted to volcanic rocks near Bariloche city, where the thickest exposures of the El Maitén Belt are found. Ages range from 23 to $20 \mathrm{Ma}$, although zircon crystallization ages of 19 Ma were also reported (Bechis et al., 2014). These volcanic successions are disposed with a NWW to NW orientation in close relationship with the development of the Nirihuau basin (Cazau et al., 1989). In this sense, it is interpreted that the emplacement of the Miocene El Maitén Belt and the arrangement of Nirihuau basin extensional structures are strongly linked to basement anisotropies (Bechis and Cristallini, 2006).

\subsection{Petrographic characterization}

\subsubsection{Eocene volcanic sequences}

Eocene volcanic rocks of the El Maitén Belt are found in the Rivadavia range $\left(\sim 43^{\circ} \mathrm{S}\right)$, to the north-west of the Esquel city (Fig. 3). The oldest part of the sequence crops out to the north of the range, consisting of middle Eocene continental sedimentary rocks, which include intercalations of carbon-rich siltstones, tuffaceous sandstones and tuffs (Fig. 4) (Sepúlveda, 1980). Atop of the sedimentary rocks, a thick volcanic sequence crops out, composed of basaltic to andesitic lava flows. In the southern extreme of Rivadavia range, upper Eocene volcanic rocks comprise a thick volcanic succession that becomes more acidic towards the top grading from basalts and basaltic andesites to dacites, with minor vitreous tuffs intercalations (37 Ma; Fernández Paz et al., 2018). Extensional tectonics may have controlled the emplacement of these volcanic rocks, as it is evidenced by wedge-like geometries associated with high-angle normal faults (Echaurren et al., 2016; Fernández Paz et al., 2018).

Regarding volcanic rocks of the sequence, the lower levels are characterized by hypabyssal basaltic intrusions with olivine phenocrysts immerse in a subophitic groundmass. However, the thickest part of the sequence is composed of basaltic andesitic to andesitic lava flows that occasionally show vesicles or autobrecciated features. They correspond to fine-grained basalts that grade into aphanitic andesites characterized by aphyric to microporphyritic textures with plagioclase, clinopyroxene, orthopyroxenes, and opaque minerals (Fig. 5a). Finally, the top of the sequence comprises andesitic to dacitic lava flows and younger dikes that show porphyritic textures with plagioclase and orthopyroxene phenocrysts within a hyalopilitic groundmass.

\subsubsection{Oligocene volcanic sequences}

Oligocene volcanic rocks of the El Maitén Belt are well distributed along the belt, including those that crop out around Cholila, Leleque and El Maitén cities, Las Bayas range, and the Ventana and Ñireco hills, near Bariloche city (Fig. 3).

From south to north, Oligocene volcanic and sedimentary rocks in the surroundings of Cholila and Leleque localities are broadly described as basaltic andesites, andesites, hypabyssal dacites, and andesitic breccias, with minor intercalations of conglomerates and volcanic breccias (32-31 Ma; Rapela et al., 1988; Rodriguez, 2010; Sosa Massaro, 2010). Basaltic andesites are porphyritic rocks with plagioclase phenocryst surrounded by an intersertal groundmass, composed of plagioclase, clinopyroxene, and magnetite. Dacites are holocrystalline rocks composed of quartz, plagioclase, and opaque minerals. Andesitic breccias comprise mainly volcanic lithics and plagioclase crystals within a volcanic groundmass. Progressive unconformities were described in the El Maitén volcanic sequences associated with high angle normal faults (Rodriguez, 2010; Sosa Massaro, 2010).

Northward, Oligocene volcanic rocks to the east of El Maitén city (Fig. 3) constitute a monotonous volcanic sequence composed of basaltic andesites and andesitic lava flows (32-25 Ma; Cazau et al., 1989; Ramos et al., 2011; Rapela et al., 1988). These rocks show microporphyritic textures with plagioclase, orthopyroxene, and clinopyroxene phenocrysts immersed in an intergranular to intersertal groundmass (Fig. 5b). An interesting feature of these rocks is the abundance of disequilibrium features as shown by in sieve textures developed in plagioclases. In the
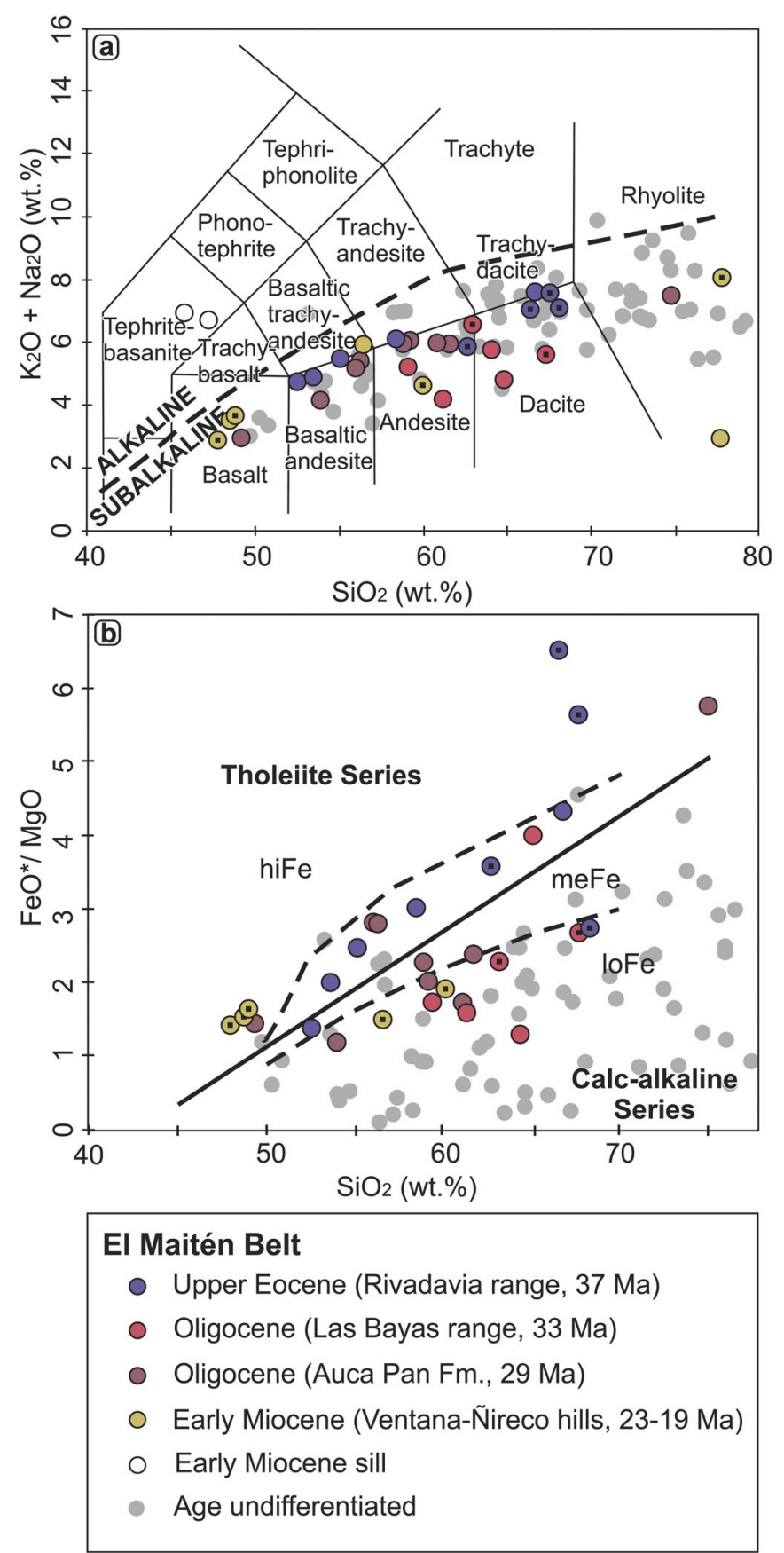

Fig. 6. (a) Total alkali versus silica classification (TAS; field limits are according to Irvine and Baragar, 1971). El Maitén Belt samples are intermediate to acidic rocks, mostly classified as basaltic andesites, andesites and dacites of subalkaline series. Subordinately, basalts, rhyolites and tephrite-basanites exist, forming part of the early Miocene samples. (b) FeOt/MgO versus $\mathrm{SiO}_{2}$ diagram. Bold line corresponds to the discriminant boundary between tholeiite and calc-alkaline series, while dashed lines discriminate between low-, medium-, and high-Fe suites (loFe, meFe and hiFe respectively) (Arculus, 2003; Miyashiro, 1974). El Maitén samples display variations in the FeOt/MgO values: upper Eocene samples plot in the meFe tholeiitic field, Oligocene samples in the meFe and loFe calc-alkaline fields, while the Miocene samples display mostly values in the hiFe tholeiitic field and minor in the loFe calc-alkaline field. Doted circles represent samples of the upper part of each sequence. See data compilation in section 4.1. 

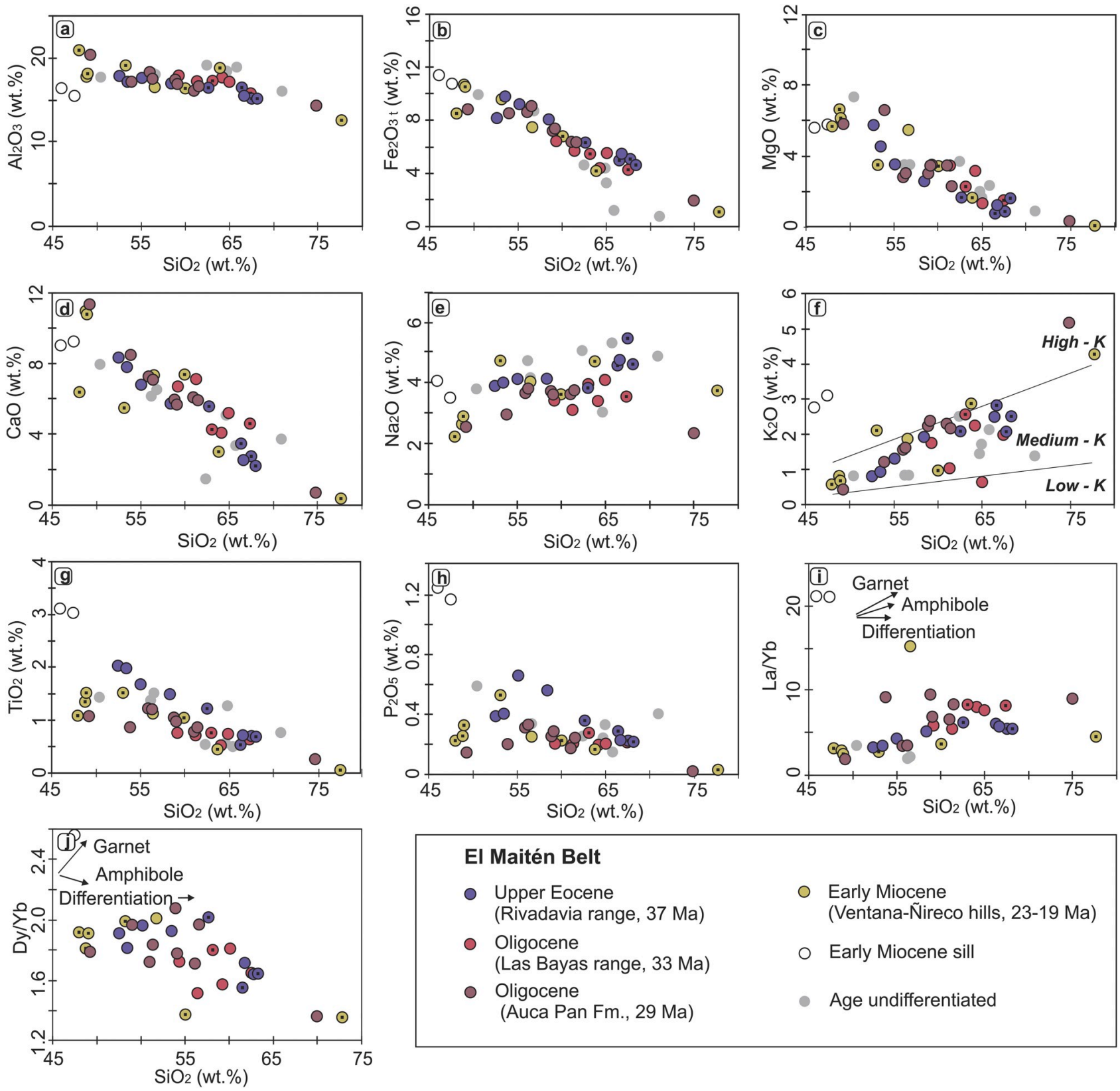

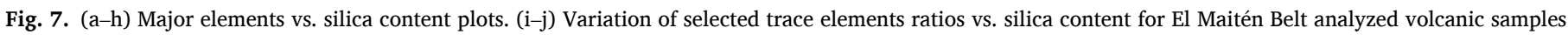
(Davidson et al., 2013). Doted circles represent samples of the upper part of each sequence. See data compilation in section 4.1.

same way, Las Bayas range section ( $\sim 41^{\circ} 30^{\prime}$; Figs. 3 and 4$)$ comprises basaltic-andesitic to andesitic lava flows with minor intercalations of volcanic breccias, tuffs, and siltstones. Andesites are porphyritic with plagioclase-amphibole phenocrysts surrounded by a felty groundmass, while basaltic andesites show microporphyritic textures with plagioclase-clinopyroxene-orthopyroxene phenocrysts within a hyalopilitic groundmass (Fig. 5c). Lapilli tuffs, tuffs, and minor volcanic breccias predominate toward the middle part of the section, occasionally interbedded with conglomerates and sandstones (Fig. 4). Finally, the upper section comprises aphyric to microporphyritic basaltic andesitic to andesitic lava flows with scarce plagioclase-clinopyroxene-orthopy roxene phenocrysts immersed in a pilotaxitic groundmass.

Volcanic rocks in the Ventana hill $\left(\sim 41^{\circ} 10^{\prime} \mathrm{S}\right)$, where the thickest records of this volcanism crop out, also yielded Oligocene ages. This section comprises $\sim 3500 \mathrm{~m}$ of sedimentary and volcanic deposits and was divided into three main members: lower, medium and upper (González Bonorino and González Bonorino, 1978). Oligocene ages
( $\sim 28 \mathrm{Ma}, \mathrm{K} / \mathrm{Ar}$ ) were obtained from the lower member of this section, while the middle and upper members were assigned to the early Miocene (Fig. 4) (Bechis et al., 2014; Rapela et al., 1988). Oligocene rocks consist of basaltic to andesitic lava flows and breccias, together with dacitic subvolcanic bodies (González Bonorino and González Bonorino, 1978).

Finally, volcanic sequences recognized north of $40^{\circ} \mathrm{S}$, represented by the Auca Pan Formation, are mainly composed of porphyritic lava flows, locally with vesicular features, and limited pyroclastic intercalations (Fig. 4) (29 Ma; Iannelli et al., 2017; Ramos et al., 2014). The porphyritic lava flows are composed of plagioclase, pyroxene, opaque minerals, and minor olivine phenocrysts immersed in an intergranular to intersertal groundmass (Fig. 5f). Pyroclastic rocks are classified as vitreous tuffs, composed of pumice fragments and minor crystal fragments: biotite, plagioclase, and opaque minerals. They are immersed in a vitreous matrix composed of volcanic ash and minor opaque minerals, showing a devitrified felsitic texture. These sequences were described as 

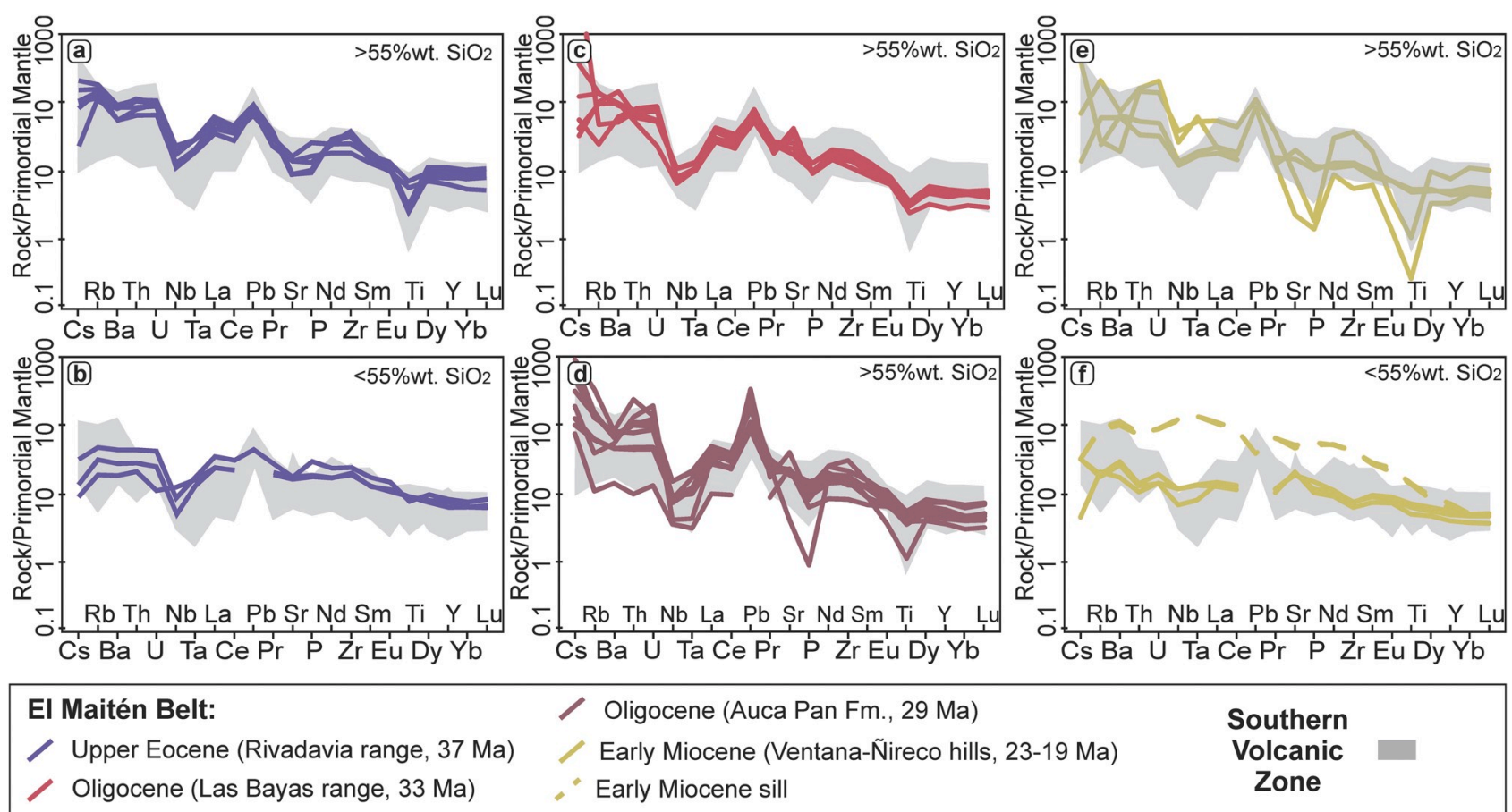

\section{Southern \\ Volcanic \\ Zone}

Fig. 8. Multielement plots normalized to primordial mantle values (Sun and McDonough, 1989). a, b) Upper Eocene samples show relatively flat patterns, with increasing arc signature toward the most evolved samples. c, d) Oligocene samples display typical arc patterns, with strong enrichment in LILE in relation to HFSE and REE. e, f) Early Miocene samples show flat patterns with less marked arc-like features, resembling E-MORB-like signature, whereas the basaltic sill shows an ocean island basalt (OIB)-like pattern. Doted circles represent samples of the upper part of each sequence See data compilation in section 4.1. The grey area corresponds to samples of the Southern Volcanic Zone (SVZ) (Jacques et al., 2013; Lara et al., 2001; Lopez-Escobar et al., 1992, 1993; Mella et al., 2005; Tobal et al., 2012; Watt et al., 2011, and references therein).

synextensional in relation to progressive unconformities in association with NNE and NW-trending normal faults and lineaments (Franzese et al., 2011; García Morabito and Ramos, 2012).

\subsubsection{Miocene volcanic sequences}

Miocene rocks are restricted to the northern part of the El Maitén Belt, forming part of the middle and upper members of the Ventana and Nireco hills section (Fig. 4) (23-19 Ma; Bechis et al., 2014; Fernández Paz et al., 2019; González Bonorino, 1973). The middle member corresponds predominantly to volcanic breccias with minor intercalations of lapillitic tuffs, tuffs, conglomerates, sandstones, and subordinate andesitic and basaltic lava flows. Lava flows are aphyric and present intergranular to intersertal assemblages of fresh plagioclase and clinopyroxene, with interstitial opaque minerals and devitrified glass. The upper member is composed of thick basaltic lava flows intercalated with lapilli tuffs, tuffs and tuffaceous siltstones, and sandstones. A fine-grained basaltic sill crosscuts the mafic lavas but is interpreted as a part of the Miocene magmatic activity, as it is coherently folded with the El Maitén Belt sequence by the Middle Miocene compressional event (Fernández Paz et al., 2019). The sedimentary record comprises marine strata that repeatedly appear within the sequence and contain abundant invertebrate fossils (Bechis et al., 2014). As described by Fernández Paz et al. (2019), basalts show microporphyritic textures either with plagioclase-clinopyroxene or olivine-plagioclase phenocryst assemblages, within intergranular to intersertal groundmasses (Fig. 5d). Contrastingly, the sill intrusion shows zoned Ti-rich clinopyroxene and olivine microphenocrysts immersed within an intergranular groundmass, composed mainly of plagioclase, clinopyroxene, biotite and opaque minerals (Fig. 5e). Tuff levels are exposed at the top of the profile and correspond to fine-grained lithic tuffs. Volcanic lithic fragments consist of microporphyritic basaltic-andesites to aphyric basalts, while vitreous fragments include pumice and shards.

\section{Geochemical and isotopic composition}

\subsection{Methodology}

Results from whole rock major and trace elements of the El Maitén Belt were compiled from Fernández Paz et al. (2018) for Eocene samples, Fernández Paz et al. (2019) and Kay et al. (2007) for Oligocene samples, Iannelli et al. (2017) for Oligocene Auca Pan Formation samples, Aragón et al. (2011a) and Fernández Paz et al. (2019) for Miocene samples, and Rapela et al. (1988) for the age undifferentiated samples.

Whole-rock $\mathrm{Sr}, \mathrm{Nd}$, and $\mathrm{Pb}$ isotopic ratios for the Oligocene and Miocene El Maitén Belt are from Fernández Paz et al. (2019), Iannelli et al. (2020) and Kay et al. (2007). In this work, we also present new isotopic data of the Eocene El Maitén Belt (Rivadavia range, Table 1). These samples were analyzed through thermal ionization mass spectrometry (TIMS) on a Triton plus instrument (Thermo Scientific) at the Isotope Geochemistry Laboratory of the Center for Marine Environmental Sciences (MARUM) at University of Bremen, Germany. Approximately $130 \mathrm{mg}$ of the pulverized samples were dissolved in a mixture of triple distilled $\mathrm{HF}^{-}$and $\mathrm{HNO}_{3}^{\overline{ }}$ in the ratio $5: 1$, dried and re-dissolved in $1000 \mu \mathrm{l}$ of $2 \mathrm{~m} \mathrm{HNO}_{3}$ for chemical separation. $\mathrm{Sr}$ and $\mathrm{Pb}$ were isolated using miniaturized columns filled with $70 \mu \mathrm{l}$ of $\mathrm{Sr}$ - and $\mathrm{Pb}$-specific resin (Sr. spec $50-100 \mu \mathrm{m}$ ). The procedure for $\mathrm{Sr}$ and $\mathrm{Pb}$ simultaneous separation from silicate samples using Sr.spec in a single-stage column was developed and detailed by Deniel and Pin (2001) and was adapted to the smaller resin volumes. The light rare earth elements (LREE) were isolated from Sr elute, using TRU.Spec (50-100 $\mu \mathrm{m})$, followed by Nd and Sm isolation with LN. Spec (50-100 $\mu \mathrm{m})$. The configuration of LREE and Sm-Nd separation columns and separation procedure were adapted from Pin and Zalduegui (1997) and Míková and Denková (2007). Total procedure blanks of Sr, Nd, and Pb were $<180 \mathrm{pg},<80 \mathrm{pg}$ and $<40 \mathrm{pg}$ respectively, being insignificant in relation to the amount of material used in the analyses. Hence, no blank 

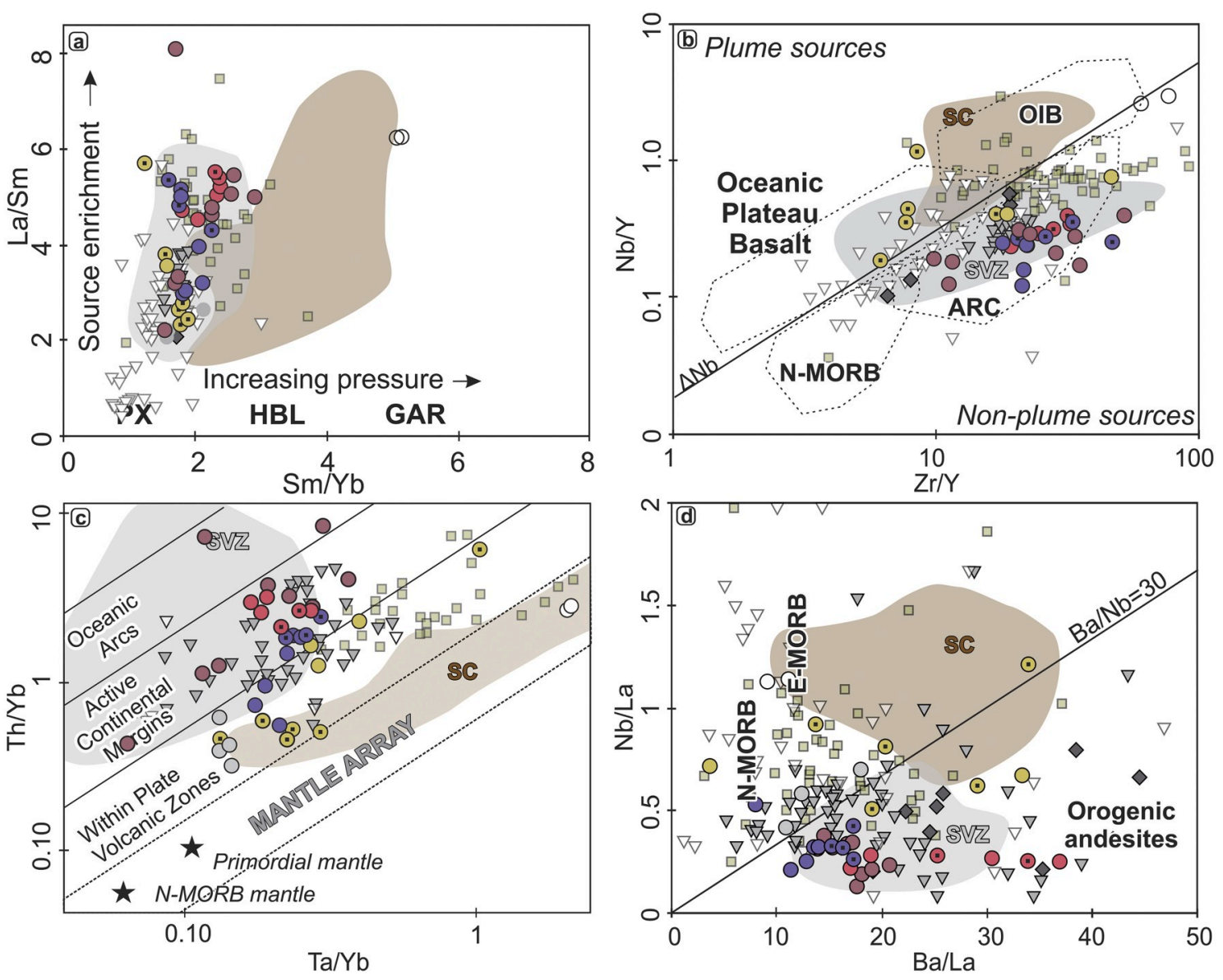

Pilcaniyeu Belt (57-42 Ma) $\square$
El Maitén Belt
0 Upper Eocene (Rivadavia range, $37 \mathrm{Ma}$ )
0 Oligocene (Las Bayas range, $33 \mathrm{Ma}$ )
0 Oligocene (Auca Pan Formation, $29 \mathrm{Ma}$ )
0 Early Miocene (Ventana-Ñireco hills, 23-19 Ma)
0 Early Miocene sill
0 Age undifferentiated

\section{Chilean magmatism \\ $\nabla$ Oligocene \\ $\nabla$ Miocene}

\section{North Patagonian Batholith (46-20 Ma) \\ Southern Volcanic Zone $8 \mathrm{VZ}$ \\ Somuncura Volcanic Province SC}

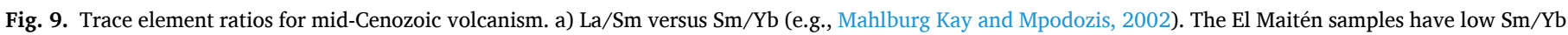

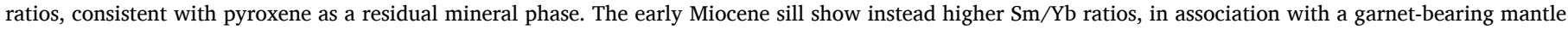

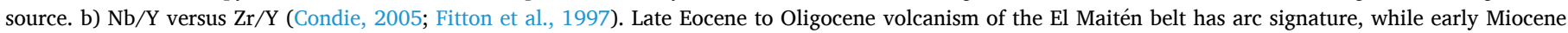

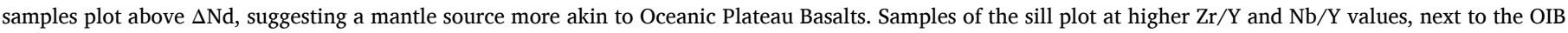

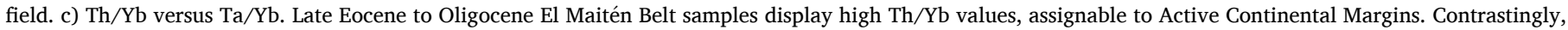

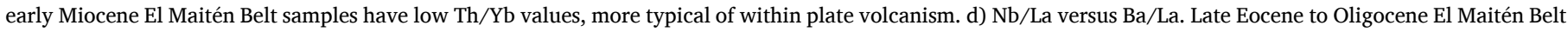

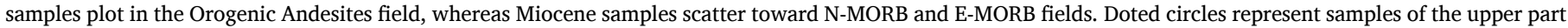

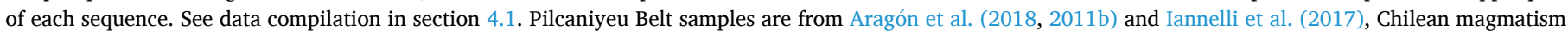

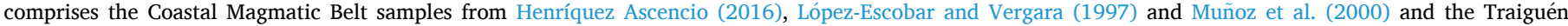

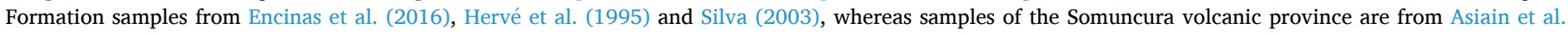
(2017), Kay et al. (2007).

corrections have been applied to analyzed ratios. Strontium collected was loaded with a Ta-oxide emitter and $0.1 \mathrm{~m} \mathrm{H}_{3} \mathrm{PO}_{4}$ on Re single filaments and Neodymium was loaded with $0.1 \mathrm{~m} \mathrm{H}_{3} \mathrm{PO}_{4}$ on a Re double filament configuration. These elements were analyzed by TIMS in dynamic multi-collection mode. Instrumental mass fractionation of $\mathrm{Sr}$ and $\mathrm{Nd}$ isotope ratios was normalized to ${ }^{86} \mathrm{Sr} /{ }^{88} \mathrm{Sr}$ of 0.1194 and ${ }^{146} \mathrm{Nd} /{ }^{144} \mathrm{Nd}$ of 0.7219 , respectively. Lead was loaded on Re single filaments with $0.1 \mathrm{~m} \mathrm{H}_{3} \mathrm{PO}_{4}$ and silica emitter, and its isotopic ratios were analyzed at pyrometer-controlled temperature of $\sim 1250{ }^{\circ} \mathrm{C}$ in static multi-collection mode. Instrumental mass-fractionation of $\mathrm{Pb}$ has been corrected using $0.1 \%$ per atomic mass unit. This factor was derived from repeated analyses of NIST 981 and a comparison of analyzed and certified $\mathrm{Pb}$ isotope ratios. The overall error, including the correction for mass-fractionation, is better than $0.1 \%$ of the respective isotope ratio.

\subsection{Geochemistry}

\subsubsection{Eocene arc-related volcanism}

Eocene volcanic rocks of El Maitén Belt (Rivadavia range, $37 \mathrm{Ma}$; Fernández Paz et al., 2018) are subalkaline basaltic andesites to dacites, which show a gradual increase in their silica content toward the top of the sequence (Fig. 6). These rocks show $\mathrm{FeO}_{\mathrm{t}} / \mathrm{MgO}$ ratios mostly comparable with tholeiitic series of medium/high-Fe. Harker plots (Fig. 7a-h) show decreasing $\mathrm{Al}_{2} \mathrm{O}_{3}, \mathrm{Fe}_{2} \mathrm{O}_{3} \mathrm{t}, \mathrm{MgO}, \mathrm{CaO}$ and $\mathrm{TiO}_{2}$ oxides 

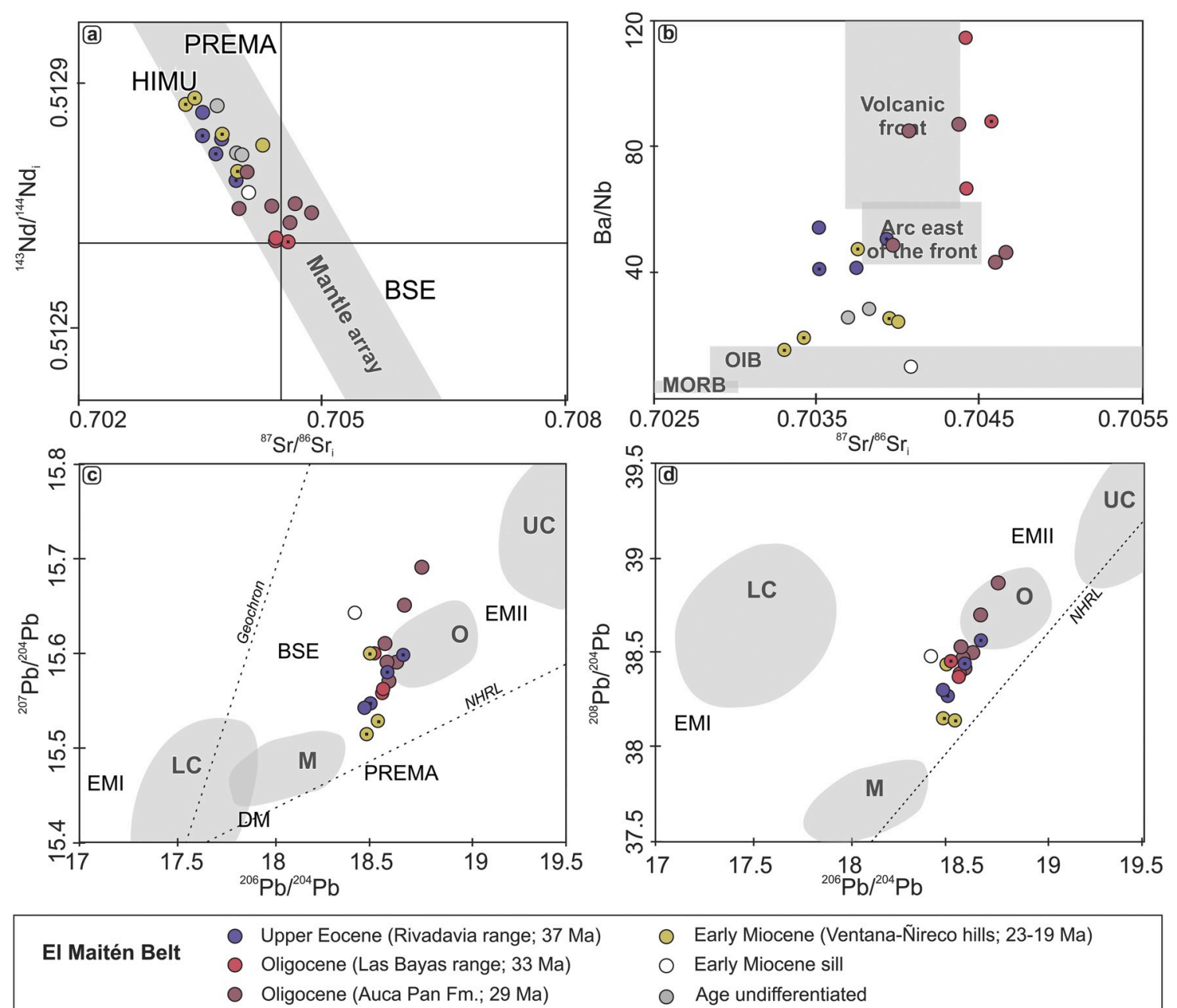
Early Miocene (Ventana-Ñireco hills; 23-19 Ma)
O Early Miocene sill
Age undifferentiated

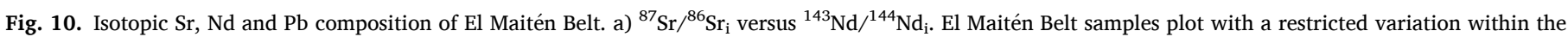

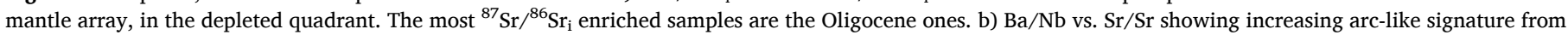

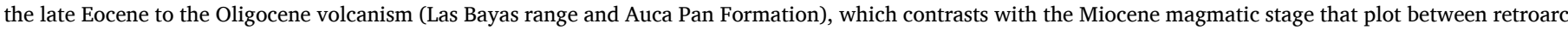

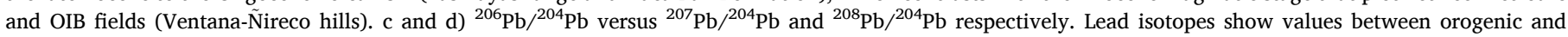

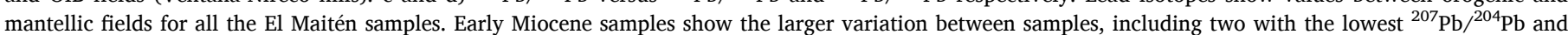

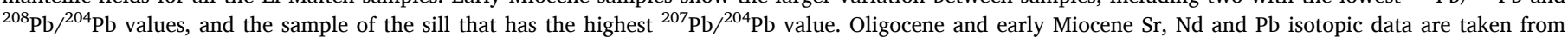

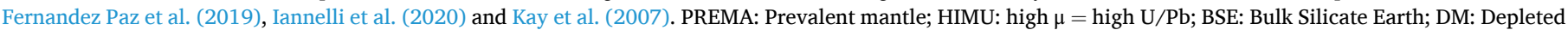

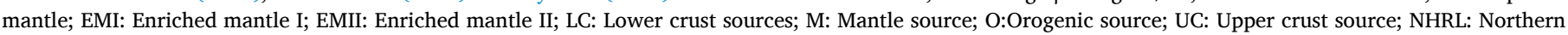
hemisphere reference line.

with $\mathrm{SiO}_{2}$, consistent with the fractionation of olivine, calcic plagioclase, clinopyroxene and ilmenite or magnetite; while the positive correlations of $\mathrm{Na}_{2} \mathrm{O}$ and $\mathrm{K}_{2} \mathrm{O}$ with silica content would indicate no alkali feldspar fractionation. $\mathrm{P}_{2} \mathrm{O}_{5}$ falls on a non-linear trend with an inflection at $\sim 55$ $\mathrm{wt} \% \mathrm{SiO}_{2}$ that reflects apatite fractionation. Trace element ratios show increasing $\mathrm{La} / \mathrm{Yb}$ and decreasing $\mathrm{Dy} / \mathrm{Yb}$ against silica, which suggest a low pressure mineral assemblage, possibly related to pyroxene or amphibole fractionation (Fig. 7i and j) (Davidson et al., 2013).

Primordial mantle-normalized multi-element diagrams are characterized by patterns with slightly $\mathrm{Rb}, \mathrm{Ba}, \mathrm{Th}, \mathrm{U}, \mathrm{La}$ and $\mathrm{Pb}$ enrichment and negative Nb-Ta, Sr-P and Ti anomalies (Fig. 8). Particularly, samples with higher silica content $\left(>55 \mathrm{wt} \% \mathrm{SiO}_{2}\right.$ ) show steeper negative anomalies in Nb-Ta, Sr-P and Ti, the latter reflecting apatite (P) and magnetite/ilmenite fractionation (Ti). These patterns are characterized by low $\mathrm{La} / \mathrm{Yb}_{\mathrm{N}}$ ratios $\left(\mathrm{La} / \mathrm{Yb}_{\mathrm{N}}=3.5-6.4\right.$, normalized to chondrite of Nakamura, 1974), that together with the low Sr/Y ratios, suggest that differentiation occurred at low pressure conditions within the crust (Davidson et al., 2013; Ducea et al., 2015; Profeta et al., 2015). In this sense, the low $\mathrm{Sm} / \mathrm{Yb}$ and $\mathrm{La} / \mathrm{Sm}$ ratios would be related to the role of pyroxene-plagioclase as a stable residual phase during magmatic differentiation and/or assimilation processes (Fig. 9a; e.g., Mahlburg Kay and Mpodozis, 2002). Magmatic source of Eocene magmas is characterized in the $\mathrm{Nb} / \mathrm{Y}$ versus $\mathrm{Zr} / \mathrm{Y}$ diagram by $\Delta \mathrm{Nb}<1$ (non-plume source), where low $\mathrm{Nb} / \mathrm{Y}$ values depict an arc related source, similar to the present arc magmas of the SVZ (Fig. 9b) (Fitton et al., 1991). Besides, late Eocene samples plot with the lowest $\mathrm{Th} / \mathrm{Yb}$ and $\mathrm{Ba} / \mathrm{La}$ values (Fig. 9c and d) within the active continental margin and orogenic andesites fields, pointing to limited slab-derived fluids contributions (e.g., low $\mathrm{Ba} / \mathrm{La}$ ratio) and sediment recycling (e.g., Low $\mathrm{Th} / \mathrm{Yb}$ ) (Hawkesworth et al., 1997; Woodhead et al., 2001).

\subsubsection{Oligocene arc volcanism}

Oligocene samples of the Las Bayas section (33 Ma; Fernández Paz et al., 2019) are andesites and dacites of the subalkaline series, with $\mathrm{FeO}_{\mathrm{t}} / \mathrm{MgO}$ values that assign them to the low-Fe calc-alkaline series (Fig. 6). On the other hand, time equivalent units to the north (Auca Pan Fm., 29 Ma; Iannelli et al., 2017) comprise subalkaline basalts to andesites, that present variable $\mathrm{FeO}_{\mathrm{t}} / \mathrm{MgO}$ ratios, plotting within the 

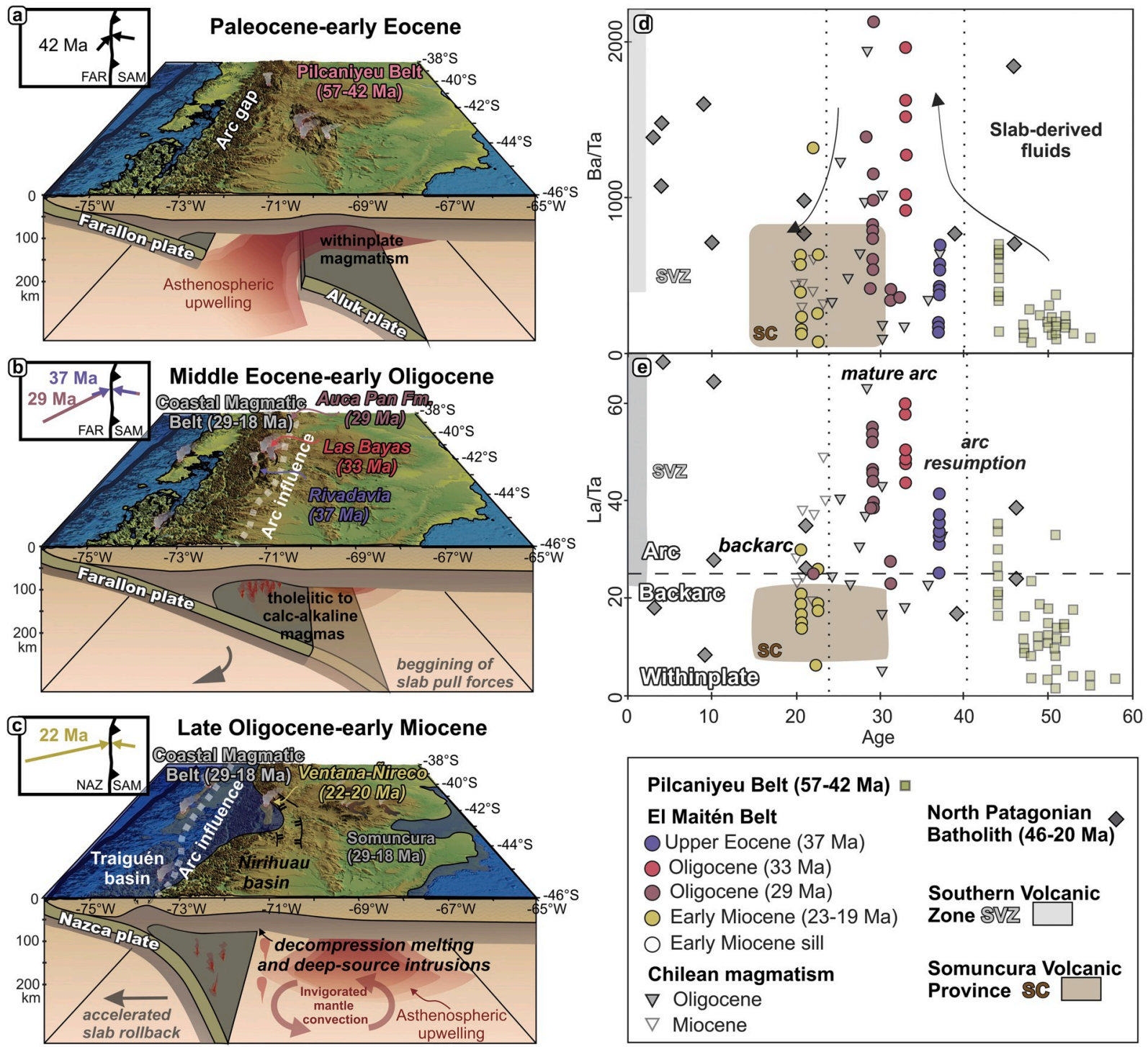

\begin{tabular}{|c|c|}
\hline \multicolumn{2}{|l|}{ Pilcaniyeu Belt (57-42 Ma) } \\
\hline $\begin{array}{l}\text { El Maitén Belt } \\
\text { Upper Eocene ( } 37 \mathrm{Ma}) \\
\text { Oligocene ( } 33 \mathrm{Ma})\end{array}$ & $\begin{array}{l}\text { North Patagonian } \\
\text { Batholith (46-20 Ma) }\end{array}$ \\
\hline $\begin{array}{l}\text { Oligocene (29 Ma) } \\
\text { Early Miocene (23-19 Ma) } \\
\text { Early Miocene sill }\end{array}$ & $\begin{array}{l}\text { Southern Volcanic } \\
\text { Zone } \$ \mathbb{Z} Z\end{array}$ \\
\hline $\begin{array}{l}\text { Chilean magmatism } \\
\nabla \text { Oligocene } \\
\nabla \text { Miocene }\end{array}$ & $\begin{array}{l}\text { Somuncura Volcanic } \\
\text { Province \&C }\end{array}$ \\
\hline
\end{tabular}

Fig. 11. a) Paleocene-early Eocene geodynamic configuration of North Patagonia. This period was characterized by the subduction of the Aluk-Farallon mid ocean ridge beneath the South American margin, which prompted the opening of a slab window and, consequently, the development of the Pilcaniyeu Belt intraplate volcanism (57-42 Ma; Aragón et al., 2013). b) Middle Eocene-early Oligocene model for the El Maitén Belt evolution, including two stages: arc establishment at 37 Ma and a mature arc period at $\sim 33 \mathrm{Ma}$. These stages were controlled by the oblique subduction of the Farallon plate at increasing convergence rates. c) Late Oligocene-early Miocene accelerated slab rollback model. Arc influence would have migrated toward the trench, coeval to the development of extensional intra and retroarc basins. In this context, the early Miocene El Maitén Belt represents a retroarc volcanism. Upper left box in a, b and c) show arrows that depict angle of convergence and plate velocities (Matthews et al., 2016). FAR=Farallon Plate; SAM= South American Plate; NAZ $=\mathrm{Nazca}$ plate. $\mathrm{d}$ and e) Age versus Ba/Ta and La/Ta respectively. Mid-Cenozoic volcanic units show variable compositions over time. After the intraplate volcanism of the Pilcaniyeu Belt, El Maitén Belt show increasing arc signature and slab-derived fluids contributions from 37 to 29 Ma. Contrastingly, the early Miocene ( 23-19 Ma) El Maitén Belt samples plot within the backarc field and show small contributions from the slab. Chilean magmatism from 29 to $19 \mathrm{Ma}$, including the Coastal Magmatic Belt, Traiguén Formation volcanism and the North Patagonian Batholith, shows a slightly higher arc signature that the El Maitén Belt but with highly variable slab contributions.

middle- and low-Fe fields of mostly calc-alkaline series. Major element trends of the studied sequences overlap with those of the Eocene samples (Fig. 7a-h), suggesting a similar pattern of crystallization and melt evolution at each system. The negative correlation of $\mathrm{Al}_{2} \mathrm{O}_{3}, \mathrm{Fe}_{2} \mathrm{O}_{3} \mathrm{t}$, $\mathrm{MgO}, \mathrm{CaO} \mathrm{TiO}_{2}$ and $\mathrm{P}_{2} \mathrm{O}_{5}$ oxides against silica content suggest olivine, calcic plagioclase, clinopyroxene, ilmenite or magnetite and apatite fractionation. $\mathrm{La} / \mathrm{Yb}$ and $\mathrm{Dy} / \mathrm{Yb}$ ratios plotted against silica display subtle trends of increasing $\mathrm{La} / \mathrm{Yb}$ and decreasing $\mathrm{Dy} / \mathrm{Yb}$, reflecting possibly amphibole fractionation (Fig. $7 \mathrm{i}$ and j) (Davidson et al., 2007). In general, primordial mantle-normalized multielement diagrams for all of the Oligocene samples show marked enrichment in large ion lithophile elements (LILE: $\mathrm{Cs}, \mathrm{Rb}, \mathrm{Ba}$, and $\mathrm{Pb}$ ) with respect to high field strength elements (HFSE: $\mathrm{Nb}, \mathrm{Ta}, \mathrm{P}$, and $\mathrm{Ti}$ ) and rare earth elements (REE: La-Lu), which is a typical pattern of arc settings (Pearce and Peate,
1995). These patterns are also characterized by negative Nb-Ta, P, and $\mathrm{Ti}$ and positive $\mathrm{Pb}$ and $\mathrm{Sr}$ anomalies (Fig. 8). Rare earth elements show steeper slopes than Eocene samples, characterized by $(\mathrm{La} / \mathrm{Yb})_{\mathrm{N}}$ ratios that vary from 6.1 to 8.4 for Las Bayas samples and from 2.3 to 9.5 for Auca Pan samples. Similarly, Oligocene samples display higher $\mathrm{Sr} / \mathrm{Y}$ (Sr/Y: 18-67 for Las Bayas samples, Sr/Y:4-52 for Auca Pan samples) and $\mathrm{Sm} / \mathrm{Yb}$ ratios (Fig. 9) than Eocene samples, which would be indicative of a deeper crustal level of magma equilibration, with amphibole as the residual mineralogy (Chapman et al., 2015; Ducea et al., 2015; Profeta et al., 2015). Oligocene magmatism is also characterized by low $\mathrm{Nb} / \mathrm{Y}$ values that reflect typical arc-related sources (Fig. 9c). The strong LILE enrichment seen in multielement diagrams is in agreement with the high $\mathrm{Ba} / \mathrm{La}$ and $\mathrm{Th} / \mathrm{Yb}$ values, which indicate high slab (fluids and sediments) and crustal contributions typical of continental arc settings 
Table 1

Initial $\mathrm{Sr}, \mathrm{Nd}, \mathrm{Pb}$ isotope ratios calculated from the measurements of the current isotope ratios (TIMS), and $\mathrm{Rb}, \mathrm{Sr}, \mathrm{Sm}, \mathrm{Nd}, \mathrm{U}, \mathrm{Th}, \mathrm{Pb}$ element concentration of whole rock samples. Element concentrations by ICP-MS, corresponds to Fernández Paz et al. (2018).

\begin{tabular}{llllll}
\hline Sample & LS04 & LS07 & LS17 & LS30B & LS29 \\
\hline${ }^{87} \mathrm{Sr} /{ }^{86} \mathrm{Sr}$ & 0.704427 & 0.704088 & 0.703601 & 0.704387 & 0.704136 \\
$\pm 2 \sigma$ & 0.000002 & 0.000002 & 0.000002 & 0.000002 & 0.000008 \\
$\left.{ }^{87} \mathrm{Sr} /{ }^{86} \mathrm{Sr}\right)_{\mathrm{i}}$ & 0.703516 & 0.703753 & 0.703518 & 0.703931 & 0.703681 \\
${ }^{143} \mathrm{Nd} /{ }^{144} \mathrm{Nd}$ & 0.512845 & 0.512841 & 0.512887 & 0.512776 & 0.512818 \\
$\pm 2 \sigma$ & 0.000005 & 0.000003 & 0.000004 & 0.000005 & 0.000008 \\
$\left.{ }^{143} \mathrm{Nd} /{ }^{144} \mathrm{Nd}\right)_{\mathrm{i}}$ & 0.512813 & 0.512808 & 0.512851 & 0.512742 & 0.512784 \\
$\varepsilon \mathrm{Nd}$ & 4.0 & 4.0 & 4.9 & 2.7 & 3.5 \\
$\varepsilon \mathrm{Nd}$ & 4.3 & 4.2 & 5.1 & 3.0 & 3.8 \\
${ }^{206} \mathrm{~Pb} /{ }^{204} \mathrm{~Pb}$ & 18.47 & & 18.49 & 18.66 & 18.52 \\
$\pm 2 \sigma$ & 0.01 & & 0.01 & 0.01 & 0.01 \\
${ }^{207} \mathrm{~Pb} /{ }^{204} \mathrm{~Pb}$ & 15.54 & & 15.55 & 15.60 & 15.55 \\
$\pm 2 \sigma$ & 0.01 & & 0.01 & 0.01 & 0.01 \\
${ }^{208} \mathrm{~Pb} /{ }^{204} \mathrm{~Pb}$ & 38.30 & & 38.27 & 38.56 & 38.30 \\
$\pm 2 \sigma$ & 0.01 & & 0.01 & 0.01 & 0.01 \\
\hline
\end{tabular}

(Fig. 9c and d) (e.g., Pearce and Peate, 1995; Plank and Langmuir, 1998).

\subsubsection{Early Miocene retroarc volcanism}

Miocene samples include subalkaline basaltic to andesitic lava flows and rhyolitic tuffs, while the sill is an alkaline tephrite-basanite (Ventana-Ñireco hills, 22-19-Ma; Fernández Paz et al., 2019). The lava flows show a trend from low-Fe calc-alkaline to high-Fe tholeiitic signatures towards the top of the sequence (Fig. 6). Harker plots show scattered correlations of major elements against silica due to the little variation in $\mathrm{SiO}_{2}$ content within the mafic samples. However, subtle trends of decreasing $\mathrm{Al}_{2} \mathrm{O}_{3}, \mathrm{Fe}_{2} \mathrm{O}_{3} \mathrm{t}, \mathrm{MgO}$, and $\mathrm{CaO}$ with increasing silica suggest olivine, calcic plagioclase and clinopyroxene fractionation, while the inflections in $\mathrm{TiO}_{2}$ and $\mathrm{P}_{2} \mathrm{O}_{5}$ around $\sim 55 \mathrm{wt} \% \mathrm{SiO}_{2}$ reflect apatite and magnetite/ilmenite fractionation. $\mathrm{La} / \mathrm{Yb}$ and $\mathrm{Dy} / \mathrm{Yb}$ ratios show little variation when plotted against silica content, suggesting pyroxene as a residual mineral at magma equilibration site (Fig. $7 \mathrm{i}$ and $\mathrm{j}$ ) (Davidson et al., 2013). Primordial mantle-normalized multielement patterns show variable LILE enrichment, which becomes less evident in samples from the upper member of the section that also lack Nb-Ta negative anomalies (Fig. 8). Their flat patterns are akin to E-MORB series, with a subtle LILE enrichment with respect to the HFSE and REE, and minor Nb-Ta or $\mathrm{Ti}$ negative anomalies (Fernández Paz et al., 2019). In accordance with these flat patterns, early Miocene samples show the lowest $\mathrm{Sm} / \mathrm{Yb}$ (Fig. 9a) and Sr/Y (Sr/Y:4-24) ratios, which reflect magma evolution within the pyroxene stability field at low pressures. Evidence of the transitional nature of these rocks comes from the $\mathrm{Nb} / \mathrm{Y}$ values that indicate an arc related mantle source $(\Delta \mathrm{Nb}<1)$ for samples of the middle member of the sequence, while the samples of the upper member display relatively high $\mathrm{Nb} / \mathrm{Y}$ ratios (0.7-2) (Fig. 9b). These higher $\mathrm{Nb} / \mathrm{Y}$ values could respond to the existence of recycled HFSE-rich components in the mantle source (Condie, 2005). Moreover, the higher $\mathrm{Nb} / \mathrm{La}$ and lower $\mathrm{Ba} / \mathrm{La}$ and $\mathrm{Th} / \mathrm{Yb}$ values of early Miocene volcanism, regarding the upper Eocene-Oligocene El Maitén Belt samples, depicts a geochemical signature more akin to within plate settings with minor slab or crustal contributions (Fig. 9c and d).

On the other hand, the subvolcanic tephrites-basanites from the sill display a clear ocean island basalts (OIB)-like pattern with enrichment in incompatible elements, $\mathrm{Pb}$ negative anomaly, and the absence of $\mathrm{Nb}$ Ta anomalies (Fig. 8). The high slopes in trace element patterns is also accompanied by high $\mathrm{La} / \mathrm{Sm}$ and $\mathrm{Sm} / \mathrm{Yb}$ ratios (Fig. 9a), that together with high $\mathrm{Sr} / \mathrm{Y}(\mathrm{Sr} / \mathrm{Y}: 30-40)$, suggest parental magma might have originated from a deep mantle source with garnet as a residual mineralogy. Moreover, the high $\mathrm{Zr} / \mathrm{Y}$ and $\mathrm{Nb} / \mathrm{Y}$ ratios indicate its connection with a mantle plume source. Consistently, $\mathrm{Th} / \mathrm{Yb}$ and $\mathrm{Ta} / \mathrm{Yb}$ ratios (Fig. 9c) are very similar to those observed in ocean island basalts (OIB)
(Sun and McDonough, 1989), suggesting that they originated from an OIB-like source.

\subsection{Isotopes}

Initial Sr and Nd isotopic signatures of the entire El Maitén Belt plot with a negative correlation into the depleted mantle quadrant (Fig. 10). Eocene samples display a relatively wide range of ${ }^{87} \mathrm{Sr} /{ }^{86} \mathrm{Sr}_{\mathrm{i}}$ (0.7036-0.7044) and ${ }^{143} \mathrm{Nd} /{ }^{144} \mathrm{Nd}_{\mathrm{i}}(0.51274-0.51285)$, with increasing in ${ }^{87} \mathrm{Sr} /{ }^{86} \mathrm{Sr}_{\mathrm{i}}$ and ${ }^{143} \mathrm{Nd} /{ }^{144} \mathrm{Nd}_{\mathrm{i}}$ toward the top of the sequence (Rivadavia range, Fig. 4). Early Oligocene magmas have uniform compositions with the lowest ${ }^{143} \mathrm{Nd} /{ }^{144} \mathrm{Nd}_{\mathrm{i}}$ and highest ${ }^{87} \mathrm{Sr} /{ }^{86} \mathrm{Sr}_{\mathrm{i}}$ ratio, whereas late Oligocene ones have higher ${ }^{143} \mathrm{Nd} /{ }^{144} \mathrm{Nd}_{\mathrm{i}}$ and lower ${ }^{87} \mathrm{Sr} /{ }^{86} \mathrm{Sr}_{\mathrm{i}}$, as most of the El Maitén Belt samples. Miocene samples, similar to the Eocene ones, display a wide range with relatively low ${ }^{87} \mathrm{Sr} /{ }^{86} \mathrm{Sr}_{\mathrm{i}}$ and high ${ }^{143} \mathrm{Nd} /{ }^{144} \mathrm{Nd}_{\mathrm{i}}$.

Lead isotope ratios show minor variability within the samples of the three periods, resembling typical values of arc magmatism between orogenic and mantellic fields (Zartman and Doe, 1981, Fig. 10 b, c). Eocene samples have ${ }^{207} \mathrm{~Pb} /{ }^{204} \mathrm{~Pb}=15.54-15.63,{ }^{208} \mathrm{~Pb} /{ }^{204} \mathrm{~Pb}=$ 38.27-38.56, and ${ }^{206} \mathrm{~Pb} /{ }^{204} \mathrm{~Pb}=18.47-18.66$. Oligocene samples show ${ }^{207} \mathrm{~Pb} /{ }^{204} \mathrm{~Pb},{ }^{208} \mathrm{~Pb} /{ }^{204} \mathrm{~Pb}$ and ${ }^{206} \mathrm{~Pb} /{ }^{204} \mathrm{~Pb}$ ratios within the range of Eocene magmatism but with slight ${ }^{207} \mathrm{~Pb} /{ }^{204} \mathrm{~Pb}$ and ${ }^{208} \mathrm{~Pb} /{ }^{204} \mathrm{~Pb}$ enrichment in some samples. It is noteworthy that the Miocene samples show the more primitive $\mathrm{Pb}$ isotopic compositions, consistent with the $\mathrm{Sr}$ and Nd isotopes. The alkaline sill presents the lowest ${ }^{206} \mathrm{~Pb} /{ }^{204} \mathrm{~Pb}$ ratio, and higher ${ }^{208} \mathrm{~Pb} /{ }^{204} \mathrm{~Pb}$ and ${ }^{207} \mathrm{~Pb} /{ }^{204} \mathrm{~Pb}$ ratios than the general trend described by most of the El Maitén Belt samples (Fig. 10 b, c).

\section{Discussion}

The El Maitén Belt volcanism developed during the late Eocene to early Miocene in the eastern slope of the North Patagonian Andes $\left(\sim 39^{\circ}\right.$ $44^{\circ} \mathrm{S}$ ) and was formally included in the Auca Pan and the Ventana formations. During its life span, it presents a variable geochemical signature associated with changes in the magmatic source, melting mechanisms and magma evolution through the crust. These changes are of great importance to understand Andean evolution, as they shed light on arc dynamics and the tectonic configuration of the North Patagonian margin throughout early and mid-Cenozoic times.

The beginning of the volcanic activity that constitutes El Maitén Belt dates from the late Eocene, after a waning of arc activity and at the end of the bimodal intraplate magmatism of the Pilcaniyeu Belt (Aragón et al., 2011b; Fernández Paz et al., 2018; Pankhurst et al., 1999). Eocene volcanic rocks are volumetrically scarce (Fig. 3), compared to Oligocene counterparts, and show wedge-like geometries in association with normal faults, indicating extensional conditions by the moment of deposition (Echaurren et al., 2016). Eocene volcanic successions are $\sim 700 \mathrm{~m}$ thick and comprise epiclastic continental deposits at the basal part, which are overlain by thick tholeiitic basaltic to dacitic lava flows, all of them intruded by andesitic dykes (Rivadavia range section; $37 \mathrm{Ma}$ ) (Fernández Paz et al., 2018). Petrographic features of the Eocene lava flows, as the scarce phenocryst content (Fig. 5 a), together with their primitive isotopic composition (Fig. 10), suggest short times of residence in magma chambers and low interaction with the crust. Geochemical features of Eocene volcanism depict an arc related signature with limited slab-derived fluids contributions and sediment recycling (e.g., relatively low $\mathrm{Ba} / \mathrm{La}$ and $\mathrm{Th} / \mathrm{Yb}$ ratios) (Fig. 9 c, d), with magmatic evolution controlled mainly by decompression melting of a slightly metasomatized mantle wedge (Fernández Paz et al., 2018). New Sr, Nd and Pb isotopic analyses support this hypothesis, since they reflect depleted sources with small variations in crustal contributions (Fig. 10). In this way, this poorly developed magmatic system, as indicated by the low-pressure mineral assemblages and extensional structural features, would have evolved through a thinned crust under extensional conditions (e.g., Ducea et al., 2015; Profeta et al., 2015). 
Oligocene volcanic rocks of the El Maitén Belt are spread all along the eastern sector of the North Patagonian Andes from $39^{\circ}$ to $44^{\circ} \mathrm{S}$, indicating a major and steady magmatic pulse when compared with previous Eocene volcanism (Figs. 1 and 3). These successions are $\sim 700-2300 \mathrm{~m}$ thick (El Maitén, Las Bayas and Auca Pan sections), mainly composed of andesitic to dacitic lava flows, volcanic breccias and tuffs, with minor sedimentary intercalations (Fig. 4). Petrographic features, such as the high phenocrysts content with disequilibrium textures (Fig. 5), indicate that these magmas experienced long residence times in magma chambers with continuous recharge. Despite local variations, Oligocene volcanic rocks have a clear calc-alkaline arc signature with strong LILE enrichment, indicating high slab contributions (e.g., high $\mathrm{Th} / \mathrm{Yb}, \mathrm{Ba} / \mathrm{La}, \mathrm{Ba} / \mathrm{Ta}, \mathrm{La} / \mathrm{Ta}$ ratios; Figs. 9 and 11). Besides, the isotopic composition of these magmas indicates variable degrees of crustal contamination (Fig. 10) (Fernández Paz et al., 2019). These geochemical features point out to a mature arc stage, developed in a slightly thicker crust than the previous stage (Fig. 11b). Still, structural features described at the northern part of the belt $\left(\sim 39^{\circ} \mathrm{S}\right)$ comprise a change in thickness and progressive unconformities in association with normal faults, indicating extensional conditions (García Morabito and Ramos, 2012).

Early Miocene volcanic rocks of the El Maitén Belt (23-19 Ma; upper member of Ventana-Ñireco section) conform a $\sim 1500$ thick succession (Figs. 3 and 4), composed of basaltic to andesitic lava flows and sills interbedded with marine epiclastic sedimentary rocks. This last stage in the evolution of the El Maitén Belt developed in association with the Nirihuau basin and the marine transgressions that flooded North Patagonia (Bechis et al., 2014). In contrast to the previous late Eocene-Oligocene volcanism, Miocene basalts have no longer arc signature, being described as E-MORB-like tholeiites and alkaline OIB intrusions with trace elements composition that resembles a retroarc setting (Figs. 8 and 9) (Fernández Paz et al., 2019). As shown by trace element ratios, early Miocene El Maitén Belt samples have a geochemical signature more akin to within plate settings with minor or remnant slab contributions (e.g., variable $\mathrm{Nb} / \mathrm{Y}, \mathrm{Th} / \mathrm{Yb}, \mathrm{Ba} / \mathrm{La}, \mathrm{Ba} / \mathrm{Ta}$ and $\mathrm{La} / \mathrm{Ta}$ ratios; Figs. 8, 9 and 11). Moreover, the coexistence of E-MORB and OIB rocks could reflect decompression melting of undepleted domains of a heterogeneous mantle wedge (Rossel et al., 2013; Turner et al., 2017; and references therein).

In a regional context, sparse magmatic activity is registered during the late Eocene, coeval with the volcanic activity of the El Maitén Belt. Small outcrops of plutonic and volcanic rocks occur along the Coastal Magmatic Belt, in the Coastal Cordillera and Central Depression ( 39-32 Ma; Henríquez Ascencio, 2016; Muñoz et al., 2000; Vergara et al., 1999), and as part of the North Patagonian Batholith, in the Chonos Archipelago ( 39-44 Ma; Pankhurst et al., 1999) (Figs. 1 and 3). The geochemical composition of these rocks show limited slab contributions, as shown by $\mathrm{Ba} / \mathrm{La}, \mathrm{La} / \mathrm{Ta}, \mathrm{Ba} / \mathrm{Ta}$ that plot within the range of arc related rocks (Figs. 10d and 11d, e).

Volcanism became widespread by late Oligocene-early Miocene times, extending from the Pacific coast to almost the Atlantic coast (Figs. 1 and 3). By the time the El Maitén Belt developed in the North Patagonian Precordillera, volcanism also took place in the Coastal Cordillera between 40 and $43^{\circ} \mathrm{S}$ (Coastal Magmatic Belt; López-Escobar and Vergara, 1997; Muñoz et al., 2000) and southward, in the Chonos Archipelago (Traiguén Formation; Encinas et al., 2016; Hervé et al., 1995). Coeval mafic plateau lavas were deposited in the North Patagonian Massif area, being included in the Somuncura volcanic province (Kay et al., 2007; Remesal et al., 2012). The volcanic rocks of the Coastal Magmatic Belt (29-18 Ma) have a bimodal composition, including andesitic-basaltic lava flows and rhyolitic to rhyodacitic pyroclastic and volcanic rocks. It is characterized by a calc-alkaline arc signature, though it also includes rocks with alkaline affinities (Henríquez Ascencio, 2016; López-Escobar and Vergara, 1997; Muñoz et al., 2000). On the other hand, volcanism within the Traiguén Formation (26-23 Ma) includes pillow basalts, dacitic to rhyolitic domes and lava flows, and pyroclastic rocks interbedded with the marine sedimentary sequences (Encinas et al., 2016; Hervé et al., 1995; Silva, 2003). The Traiguén Formation comprise MORB and E-MORB volcanic rocks with trace elements that show an incipient arc signature in its early stages, whereas the last stages are dominated by E-MORB and OIB rocks (Silva, 2003). Overall, trace element ratios of the late Oligocene Coastal Magmatic Belt samples show arc-related sources with high $\mathrm{Th} / \mathrm{Yb}, \mathrm{Ba} / \mathrm{La}, \mathrm{Ba} / \mathrm{Ta}, \mathrm{La} / \mathrm{Ta}$ values, suggesting slab contributions (Figs. 9 and 11). Instead, early Miocene samples of Coastal Magmatic Belt and the Traiguén Formation volcanism show slightly lower $\mathrm{Ba} / \mathrm{La}, \mathrm{Th} / \mathrm{Yb}, \mathrm{Ba} / \mathrm{Ta}$ and $\mathrm{La} / \mathrm{Ta}$ ratios than Oligocene samples, and variable $\mathrm{Nb} / \mathrm{Y}, \mathrm{Nb} / \mathrm{La}$ and $\mathrm{Ta} / \mathrm{Yb}$ ratios (Figs. 9 and 11), suggesting minor slab contributions and a heterogeneous mantle source (Muñoz et al., 2000).

Contrastingly, the Somuncura volcanic province, developed in the North Patagonian Massif (Fig. 1), comprise tholeiitic-alkaline, OIB-like plateau basalts associated with an asthenospheric upwelling (e.g., Asiain et al., 2017; De Ignacio et al., 2001; Kay et al., 2007). Trace element ratios for this volcanism show high $\mathrm{Sm} / \mathrm{Yb}$ values, reflecting its derivation from a deep garnet-bearing source (Fig. 9a). Moreover, these rocks have high $\mathrm{Nb}$ and $\mathrm{Ta}$ content, and thus high $\mathrm{Nb} / \mathrm{Y}, \mathrm{Nb} / \mathrm{La}$ and $\mathrm{Ta} / \mathrm{Yb}$, and low $\mathrm{Th} / \mathrm{Yb}, \mathrm{Ba} / \mathrm{Ta}$ and $\mathrm{La} / \mathrm{Ta}$ values typical of a within plate volcanism (Figs. 9 and 11).

Great controversies exist about the geodynamic configuration of the North Patagonian margin during early Cenozoic arc evolution and the extensional regime developed by this time. It has been proposed that during the Paleogene, the Aluk-Farallon mid-ocean ridge was subducted beneath the South American Plate at North Patagonia latitudes, triggering the opening of a slab window and mantle upwelling, which was responsible of Pilcaniyeu Belt magmatism (Fig. 11a) (e.g., Aragón et al., 2013; Cande and Leslie, 1986; Iannelli et al., 2020). There are two opposed models that explain the tectonic evolution of the margin after the subduction of this mid ocean ridge: 1) an strike slip plate margin (Aragón et al., 2019, 2013, 2011b); and 2) a slab rollback-dominated setting (e.g., Fennell et al., 2018; Fernández Paz et al., 2019; Jordan et al., 2001; Muñoz et al., 2000). In the first case, after ridge collision with the South American margin, the Farallon plate would have continued its subduction with a low convergence angle, promoting its segmentation into subducting microplates and strike slip plate margin segments (Aragon et al., 2011a,b; Gianni et al., 2018). These latitudinal segments limited by transform faults would have promoted extension, uplift and bimodal volcanism in the foreland zone. In opposition, the second model considers that after ridge subduction, subduction continued and when the slab pull force was restored, the convergence velocity increased, the trench hinge retreated away from the upper plate and the slab steepened (Fennell et al., 2018). Slab rollback would have promoted extensional conditions in the upper plate, a fast subsiding regime allowing marine transgressions, the migration or broadening of the magmatic arc, and the income of deep sourced magmas into the mantle wedge (Encinas et al., 2016; Fennell et al., 2018; Fernández Paz et al., 2019; Jordan et al., 2001; Muñoz et al., 2000).

In this context, the evolution of the El Maitén Belt volcanism, with the active subduction of the Farallón plate beneath the South American margin, does not fit with the strike slip plate margin model and it is more consistent with the slab rollback model (Fig. 11b). After the AlukFarallón ridge was entirely subducted, the influence of the subducting slab is registered in both the late Eocene El Maitén Belt volcanic rocks and the satellite bodies of the North Patagonian Batholith and the Coastal Magmatic Belt (Fernández Paz et al., 2018; Henríquez Ascencio, 2016; Muñoz et al., 2000; Pankhurst et al., 1999; Vergara et al., 1999) (Fig. 11 d, e). By this time, the oblique subduction of the Farallón plate began with moderate stable rates (Matthews et al., 2016; Somoza and Ghidella, 2012, Fig.11 a and b). The oblique subduction of the young and hot slab would have limited the extent of magmatic activity, triggered by decompression melting at shallow depths (Fernández Paz et al., 2018; Govers and Meijer, 2001; Lee et al., 2009). Moreover, the extensional regime developed in the upper plate would have promoted the rapid 
ascent of melts, resulting in the tholeiitic and depleted isotopic composition of the Late Eocene El Maitén Belt magmas, which show no appreciable crustal contamination and limited slab contributions (Fig.11 d, e).

By the Oligocene, the El Maitén Belt volcanism evolved to a mature arc signature, with a high intake of slab derived fluids and crustal contributions (Fernández Paz et al., 2019) (Fig. 11d and e). This mature arc stage took place contemporaneously with an increment in convergence rates of the Farallon plate beneath the South American plate (Matthews et al., 2016). These conditions would have promoted higher fluid flux melting rates and, thus, an increased magma production, giving rise to the widespread, calc-alkaline and thick Oligocene volcanic sequences (Fig. 11b). By the same time, arc-related activity is recognized far to the west, along the Coastal Cordillera as the Coastal Magmatic Belt, suggesting an expanded arc configuration. This scenario is not rare in continental arcs bounded to extensional conditions, as is the case of the early Andean subduction system, which developed as two parallel belts with subduction-related signature but with systematical differences from frontal arc magmatism (Rossel et al., 2013).

An important change in the paleogeography, the location of volcanism and the tectonic conditions occurred by the latest Oligocene-early Miocene, interrupting arc activity over the El Maitén Belt. Arc influence appears to have migrated toward the west, since arc-related signature could be only identified in the present forearc: the Coastal Magmatic Belt, the Traiguén Formation and the restricted suites of the North Patagonian Batholith (Fig. 11d). By this time, early Miocene volcanism of the El Maitén Belt no longer represents arc activity. Instead, E-MORB lava flows with retroarc signature would have been associated with decompression melting in the retroarc zone, while the alkaline OIB intrusions could have been related to the income of deeply sourced magmas (Fernández Paz et al., 2019). This widespread volcanism coincided with regional extensional conditions that controlled magmatic emplacement and promoted the development of fore, intra and back-arc basins all along the South American margin (Bechis et al., 2014; Charrier et al., 2009, 2002, 1996; Encinas et al., 2016; Jordan et al., 2001). This is also suggested by the poorly differentiated character of the gabbroic suites of the North Patagonian Batholith, emplaced preferentially west of the main trace of the Liquiñe-Ofqui Fault Zone (Pankhurst et al., 1999). In a tectonic framework, this last stage is contemporaneous with the increasing convergence rates and decreasing obliquity of the Farallon plate (28-26 Ma), which ended with the final break-up of Farallon plate into Nazca and Cocos plates, and the beginning of the orthogonal subduction of the Nazca plate with high convergence rates (Cande and Leslie, 1986; Lonsdale, 2005; Matthews et al., 2016). Numerical modeling of subduction zone dynamics suggests that the orthogonal subduction at high convergence rate could have promoted an accelerated rollback of the slab and led to the development of an extensional regime in the upper plate (Fennell et al., 2018; Jordan et al., 2001; Muñoz et al., 2000). In this sense, Aragón et al. (2019) argue that slab rollback in east-dipping subduction zones is not possible since the eastward mantle flow tends to sustain the slab angle. However, during this major tectonic reorganization, the increase in convergence rate and the change in the subduction zone configuration (from oblique to orthogonal) would have generated a strong subduction-induced mantle flow (Fennell et al., 2018; Fernández Paz et al., 2019). This induced flow in the mantle wedge would have triggered decompression melting in the retroarc zone and the upward flux of material from significant depths (Brandl et al., 2017; Faccenna et al., 2010; Gao et al., 2018; Kincaid and Griffiths, 2004; Staudigel and King, 1992), explaining the coexistence of subduction-related volcanism with rocks of OIB affinity both in the arc and the retroarc zone (Fig. 11c) (Faccenna et al., 2010; Fernández Paz et al., 2019).

Therefore, we interpret that the variable geochemical signature of the El Maitén Belt, in terms of its similarity to both arc and/or within plate settings, reflects an evolving magmatic system closely linked to the configuration of the subduction zone. First, the El Maitén Belt is located in an unusual position when compared to cordilleran arcs, i.e., taking place $300 \mathrm{~km}$ away from the present trench configuration instead of the average distance of 100-150 km (Figs. 1 and 3) (Grove et al., 2012; Stern, 2002). Secondly, the El Maitén Belt comprises different stages on its magmatic evolution, characterized by a geochemical signature that reflects a variable intake of slab derived fluids, sediments and crustal contributions, together with the income of enriched melts in the last stages. In this sense, we could differentiate an Eocene arc resumption, an early Oligocene mature arc, and a late Oligocene-early Miocene retroarc stage. Moreover, the El Maitén Belt volcanism is strongly controlled by the extensional regime that developed in the North Patagonian Andes during the early Cenozoic. In this sense, El Maiten Belt, together with the Coastal Magmatic Belt, represents an expanded arc configuration from the late Eocene to the late Oligocene, which ends up with a retroarc volcanism that occurs in association with an important marine transgression.

\section{Conclusions}

The volcanic rocks of the El Maitén Belt reflects arc activity in the North Patagonian Andes from the upper Eocene to the late? Oligocene. Through its evolution, the El Maitén Belt depicts a good example of how a magmatic arc establishes, evolves, migrates and/or finally disappears in association with changes in the subduction zone configuration.

Late Eocene El Maitén Belt characterizes the re-installment of arcrelated magmatism after the collision of the Aluk-Farallon mid-ocean ridge. These first arc products consist of restricted outcrops of tholeiitic basalts, basaltic andesites and andesites, with trace element ratios that resemble an arc setting with scarce contributions of the subducted slab. This low volume magmatism would have been generated by decompression melting of the asthenospheric mantle wedge, controlled by the oblique subduction of the Farallon plate beneath the South American plate.

Mature arc conditions were achieved by the Oligocene, when a calcalkaline arc front volcanism emplaced all along the North Patagonian Precordillera. Geochemically, Oligocene El Maitén Belt comprises intermediate volcanic rocks with important fluid, sediment and crustal intake in the magma source. This stage would have been promoted by the increase in the convergence rates between the Farallon plate and the South American plate.

Finally, arc activity ceases in the North Patagonian Andes by the early Miocene, while El Maitén Belt continues its volcanism with a retroarc signature. Early Miocene volcanism consist of basalts and basaltic andesites interbedded with marine deposits, whose deposition was controlled by the widespread extensional conditions developed by this time. In a geodynamic context, the end of the El Maitén Belt as a magmatic arc was associated with the slab rollback of the Nazca plate, the migration of arc magmatism toward the trench and the development of a slab induced mantle flow that promoted decompression melting behind the arc.

\section{Declaration of competing interest}

The authors declare that they have no known competing financial interests or personal relationships that could have appeared to influence the work reported in this paper.

\section{Acknowledgments}

The authors thank the editor, the managing guest editor, Cesar Navarrete, and the two reviewers, Juan Otamendi and Juan Díaz Alvarado, for their constructive reviews that significantly improved the previous version of the manuscript. This work was financially supported by CONICET (Grant 11220150100426CO), University of Buenos Aires (grant UBACYT 20020150100166BA), ANPCyT (PICT-2012-1490, PICT2014- 2240, and PICT-2017-3259), and Fondecyt (1151146). This is the 
R 348 contribution of the Instituto de Estudios Andinos "Don Pablo Groeber".

\section{Appendix A. Supplementary data}

Supplementary data to this article can be found online at https://doi. org/10.1016/j.jsames.2020.102713.

\section{References}

Aragón, E., Castro, A., Díaz-Alvarado, J., Liu, D.-Y.Y., 2011a. The North Patagonian batholith at Paso Puyehue (Argentina-Chile). SHRIMP ages and compositional features. J. South Am. Earth Sci. 32, 547-554. https://doi.org/10.1016/j. jsames.2011.02.005.

Aragón, E., Castro, A., Diaz-Alvarado, J., Pinotti, L., D'eramo, F., Demartis, M., Coniglio, J., Hernando, I., Rodriguez, C., 2018. Mantle derived crystal-poor rhyolitic ignimbrites: eruptive mechanism from geochemical and geochronological data of the Piedra Parada caldera, Southern Argentina. Geosci. Front. Times 9, 1529-1553. https://doi.org/10.1016/j.gsf.2017.09.004.

Aragón, E., D’Eramo, F., Castro, A., Pinotti, L., Brunelli, D., Rabbia, O., Rivalenti, G., Varela, R., Spakman, W., Demartis, M., Cavarozzi, C.E., Aguilera, Y.E., Mazzucchelli, M., Ribot, A., 2011b. Tectono-magmatic response to major convergence changes in the North Patagonian suprasubduction system; the Paleogene subduction-transcurrent plate margin transition. Tectonophysics 509, 218-237. https://doi.org/10.1016/j.tecto.2011.06.012.

Aragón, E., Fernando, D., Cuffaro, M., Doglioni, C., Ficini, E., Lucio, P., Nacif, S., Manuel, D., Irene, H., Tomás, F., 2019. The westward lithospheric drift, its role on the subduction and transform zones surrounding Americas: Andean to Cordilleran orogenic types cyclicity. Geosci. Front. https://doi.org/10.1016/j.gsf.2019.11.002.

Aragón, E., Pinotti, L., D’eramo, F., Castro, A., Rabbia, O., Coniglio, J., Demartis, M., Hernando, I., Cavarozzi, C.E., Aguilera, Y.E., 2013. The Farallon-Aluk ridge collision with South America: implications for the geochemical changes of slab window magmas from fore- to back-arc. Geosci. Front. 4, 377-388. https://doi.org/10.1016/ j.gsf.2012.12.004.

Arculus, R.J., 2003. Use and abuse of the terms calcalkaline and calcalkalic. J. Petrol. 44, 929-935. https://doi.org/10.1093/petrology/44.5.929.

Asiain, L., Gargiulo, M.F., Reitinger, J., Ntaflos, T., Bjerg, E.A., 2017. Petrografía y geoquímica de lavas básicas del sector noroeste de la meseta de somuncurá, Provincia De Río Negro. Rev. la Asoc. Geol. Argentina 74, 570-582.

Bechis, F., Cristallini, E.O., 2006. Inflexiones en estructuras del sector norte de la faja plegada y corrida de Nirihuau, provincia de Río Negro. Asoc. Geológica Argentina, Ser. Publicación Espec. 6, 18-25.

Bechis, F., Encinas, A., Concheyro, A., Litvak, V.D., Aguirre-Urreta, B., Ramos, V.A., 2014. New age constraints for the Cenozoic marine transgressions of northwestern Patagonia, Argentina $\left(41^{\circ}-43^{\circ} \mathrm{S}\right)$ : paleogeographic and tectonic implications. J. South Am. Earth Sci. 52, 72-93. https://doi.org/10.1016/j.jsames.2014.02.003.

Benedini, L., Geraldes, M., Gregori, D.A., Strazzere, L., Marcos, P., Barros, M., 2017. Nueva edad U-Pb Eocena tardía para la Formación Ventana, Andes Nordpatagónicos, Provincia de Río Negro. XX Congreso Geológico Argentino. San Miguel de Tucumán, pp. 7-11.

Brandl, P.A., Hamada, M., Arculus, R.J., Johnson, K., Marsaglia, K.M., Savov, I.P., Ishizuka, O., Li, H., 2017. The arc arises: the links between volcanic output, arc evolution and melt composition. Earth Planet Sci. Lett. 461, 73-84. https://doi.org/ 10.1016/j.epsl.2016.12.027.

Breitsprecher, K., Thorkelson, D.J., 2009. Neogene kinematic history of nazca-antarcticphoenix slab windows beneath Patagonia and the antarctic peninsula. Tectonophysics 464, 10-20. https://doi.org/10.1016/j.tecto.2008.02.013.

Butler, K.L., Horton, B.K., Echaurren, A., Folguera, A., Fuentes, F., 2020. CretaceousCenozoic growth of the Patagonian broken foreland basin, Argentina: chronostratigraphic framework and provenance variations during transitions in Andean subduction dynamics. J. South Am. Earth Sci. 97 https://doi.org/10.1016/j. jsames.2019.102242.

Cande, S.C., Leslie, R.B., 1986. Late cenezoic tectonics of the southern Chile trench. Geophys. Res. 91, 471-496.

Cazau, L., 1972. Cuenca de Nirihuau-Ñorquinco-Cushamen. Geol. Reg. Argentina $727-740$.

Cazau, L., Mancini, S., Cangini, J., Spalletti, L.A., Chebli, G., 1989. Cuenca de Ñirihuau. Cuencas Sedimentarias Argentinas. Instituto Superior de Correlación Geológica, Universidad Nacional de Tucumán San Miguel de Tucumán, pp. 299-318.

Cembrano, J., Lara, L., 2009. The link between volcanism and tectonics in the southern volcanic zone of the Chilean Andes: a review. Tectonophysics 471, 96-113. https:// doi.org/10.1016/j.tecto.2009.02.038.

Chapman, J.B., Ducea, M.N., DeCelles, P.G., Profeta, L., 2015. Tracking changes in crustal thickness during orogenic evolution with $\mathrm{Sr} / \mathrm{Y}$ : an example from the North American Cordillera. Geology 43, 919-922. https://doi.org/10.1130/G36996.1.

Charrier, R., Baeza, O., Elgueta, S., Flynn, J.J., Gans, P., Kay, S.M., Muñoz, N., Wyss, A. R., Zurita, E., Muñoz, N., Wyss, A.R., Zurita, E., 2002. Evidence for Cenozoic extensional basin development and tectonic inversion south of the flat-slab segment,

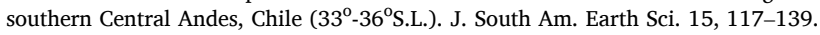
https://doi.org/10.1016/S0895-9811(02)00009-3.

Charrier, R., Farías, M., Maksaev, V., 2009. Evolución tectónica, paleográfica y metalogénica durante el cenozoico en los Andes de Chile norte y central e implicaciones para las regiones adyacentes de Bolivia y Argentina. Rev. la Asoc. Geol. Argentina 65, 5-35.

Charrier, R., Wyss, A.R., Flynn, J.J., Swisher, C.C., Norell, M.A., Zapatta, F., McKenna, M. C., Novacek, M.J., Swisher III, C.C., Norell, M.A., Zapatta, F., McKenna, M.C., Novacek, M.J., 1996. New evidence for late mesozoic-early Cenozoic evolution of the Chilean Andes in the upper Tinguiririca valley ( $\left.35^{\circ} \mathrm{S}\right)$, central Chile. J. South Am. Earth Sci. 9, 393-422. https://doi.org/10.1016/S0895-9811(96)00035-1.

Coira, B.L., 1979. Descripción geológica de la Hoja 40 d, ingeniero jacobacci. Servicio Geológico Nacional.

Condie, K.C., 2005. High field strength element ratios in Archean basalts : a window to evolving sources of mantle plumes? Lithos 79, 491-504. https://doi.org/10.1016/j. lithos.2004.09.014.

Dalla Salla, L., Leguizawjn, M., Mazzoni, M., Rapela, C., Spalletti, L., 1981. Características del vulcanismo paleógeno en la cordillera Nordpatagónica entre las latitudes $39^{\circ} 30^{\prime}$ y $41^{\circ} 20^{\prime}$ S. VIII Congreso Geológico Argentino, pp. 629-657. San Luis.

Davidson, J., Turner, S., Handley, H., Macpherson, C., Dosseto, A., 2007. Amphibole "sponge" in arc crust? Geology 35, 787-790. https://doi.org/10.1130/G23637A.1.

Davidson, J., Turner, S., Plank, T., 2013. Dy/Dy*: variations arising from mantle sources and petrogenetic processes. J. Petrol. 54, 525-537. https://doi.org/10.1093/ petrology/egs076.

De Ignacio, C., López, I., Oyarzún, R., Márquez, A., 2001. The northern Patagonia Somuncura plateau basalts: a product of slab-induced, shallow asthenospheric upwelling? Terra. Nova 13, 117-121.

Deniel, C., Pin, C., 2001. Single-stage method for the simultaneous isolation of lead and strontium from silicate samples for isotopic measurements. Anal. Chim. Acta 426, 95-103. https://doi.org/10.1016/S0003-2670(00)01185-5.

Dessantí, R.N., 1972. Andes patagónicos septentrionales. Geol. Reg. Argentina 655-697.

Ducea, M.N., Saleeby, J.B., Bergantz, G., 2015. The architecture, chemistry, and evolution of continental magmatic arcs. Annu. Rev. Earth Planet Sci. 43, 299-333. https://doi.org/10.1146/annurev-earth-060614-105049.

Echaurren, A., Folguera, A., Gianni, G., Orts, D.L., Tassara, A., Encinas, A., Giménez, M., Valencia, V.A., 2016. Tectonic evolution of the North Patagonian Andes (41-44 S) through recognition of syntectonic strata. Tectonophysics 677, 99-114. https://doi. org/10.1016/j.tecto.2016.04.009.

Echaurren, A., Oliveros, V., Folguera, A., Ibarra, F., Creixell, C., Lucassen, F., 2017. Early Andean tectonomagmatic stages in north Patagonia: insights from field and geochemical data. J. Geol. Soc. London. 174, 405-421. https://doi.org/10.1144/ jgs2016-087.

Encinas, A., Folguera, A., Oliveros, V., De Girolamo Del Mauro, L., Tapia, F., Riffo, R., Hervé, F., Finger, K.L., Valencia, V.A., Gianni, G., Álvarez, O., 2016. Late Oligoceneearly Miocene submarine volcanism and deep-marine sedimentation in an extensional basin of southern Chile: implications for the tectonic development of the North Patagonian Andes. Bull. Geol. Soc. Am. 128, 807-823. https://doi.org/ 10.1130/B31303.1.

England, P.C., Katz, R.F., 2010. Melting above the anhydrous solidus controls the location of volcanic arcs. Nature 467, 700-703. https://doi.org/10.1038/ nature09417.

Faccenna, C., Becker, T.W., Lallemand, S., Lagabrielle, Y., Funiciello, F., Piromallo, C., 2010. Subduction-triggered magmatic pulses: a new class of plumes? Earth Planet Sci. Lett. 299, 54-68. https://doi.org/10.1016/j.epsl.2010.08.012.

Fennell, L.M., Quinteros, J., Iannelli, S.B., Litvak, V.D., Folguera, A., Iannelli, B., Litvak, V.D., 2018. The role of the slab pull force in the late Oligocene to early Miocene extension in the Southern Central Andes $\left(27^{\circ}-46^{\circ} \mathrm{S}\right)$ : insights from numerical modeling. J. South Am. Earth Sci. 1-14. https://doi.org/10.1016/j. jsames.2017.12.012.

Fernández Paz, L., Bechis, F., Litvak, V.D., Echaurren, A., Encinas, A., González, J., Lucassen, F., Oliveros, V., Valencia, V., Folguera, A., 2019. Constraints on trenchward arc migration and backarc magmatism in the north patagonian Andes in the context of Nazca plate rollback. Tectonics 38, 1-24. https://doi.org/10.1029/ 2019 TC005580.

Fernández Paz, L., Litvak, V.D., Echaurren, A., Iannelli, S.B., Encinas, A., Folguera, A., Valencia, V., 2018. Late eocene volcanism in north Patagonia $\left(42^{\circ} 30^{\prime}-43^{\circ} \mathrm{S}\right)$ : arc resumption after a stage of within-plate magmatism. J. Geodyn. 113, 13-31. https:// doi.org/10.1016/j.jog.2017.11.005.

Feruglio, E., 1941. Nota preliminar sobre la hoja 40b, San Carlos de Bariloche. Bol. Inf. Pet. (1924) 18, 26-64.

Feruglio, E., 1927. Estudio geológico de la región pre y subandina en la latitud de Nahuel Huapí. Bol. Inf. Pet. (1924) 4, 425-434.

Fitton, J.G., James, D., Leeman, W.P., 1991. Basic magmatism associated with Late Cenozoic extension in the western United States: compositional variations in space and time. J. Geophys. Res. 96, 13693. https://doi.org/10.1029/91JB00372.

Fitton, J.G., Saunders, A.D., Norry, M.J., Hardarson, B.S., Taylor, R.N., 1997. Thermal and chemical structure of the Iceland plume. Earth Planet Sci. Lett. 153, 197-208.

Franzese, J.R., D’Elia, L., Bilmes, A., Muravchik, M., Hernández, M., 2011. Superposición de cuencas extensionales y contraccionales oligo-miocenas en el retroarco andino norpatagónico: La cuenca de aluminé, neuquén, Argentina. Andean Geol. 38, 319-334.

Gao, Z., Zhang, H.F., Yang, H., Pan, F. Bin, Luo, B.J., Guo, L., Xu, W.C., Tao, L., Zhang, L. Q., Wu, J., 2018. Back-arc basin development: constraints on geochronology and geochemistry of arc-like and OIB-like basalts in the Central Qilian block (Northwest China). Lithos 310-311, 255-268. https://doi.org/10.1016/j.lithos.2018.04.002.

García Morabito, E., Ramos, V.A., 2012. Andean evolution of the aluminé fold and thrust belt, northern patagonian Andes (38 $30^{\prime}-40^{\circ} 30^{\prime}$ S). J. South Am. Earth Sci. 38, 13-30. https://doi.org/10.1016/j.jsames.2012.03.005. 
Giacosa, R.E., Heredia, N.C., 2002. Hoja geológica 4172-IV, san carlos de Bariloche. Provincias de Río Negro y Neuquén. Inst. Geol. y Recur. Miner. Serv. Geológico Min. Argentino. Boletín vol. 27, 77. Buenos Aires.

Gianni, G.M., Echaurren, A., Fennell, L., Navarrete, C., Quezada, P., Tobal, J.E., Gimenez, M.E., Dávila, F.M., Folguera, A., 2018. Creataceous orogeny and marine transgressions in the Southern Central and Northern Patagonian Andes: aftermath of a large-scale flat subduction event? In: Folguera, A., Contreras-Reyes, E., Heredia, N., Arriagada, C., Encinas, A., Iannelli, S.B., Oliveros, V., Dávila, F.M., Collo, G., Giambiagi, L., Maksymowicz, A., Iglesia Llanos, M.P., Turienzo, M., Naipauer, M., Orts, D.L., Litvak, V.D., Alvarez, O., Arriagada, César (Eds.), The Evolution of the Chilean-Argentinean Andes. Springer, pp. 279-316. https://doi.org/10.1007/978-3319-67774-3.

González Bonorino, F., 1973. Geología del área entre San Carlos de Bariloche y Llao Llao, Publicación 16. Fundacion Bariloche, Departamento de Recursos Naturales y Energía.

González Bonorino, F., González Bonorino, G., 1978. Geología de la region de San Carlos de Bariloche. Rev. la Asoc. Geológica Argentina 33, 175-210.

González Díaz, E.F., 1979. La edad de la Formación Ventana, en el área al norte y al este del Lago Nahuel Huapi. Rev. la Asoc. Geológica Argentina 34, 113-124.

Gordon, A., Ort, M.H., 1993. Edad y correlación del plutonismo subcordillerano en las provincias de Río Negro y Chubut (41-42 30'LS). VII Congreso Geológico Argentino, pp. 120-127. Mendoza.

Govers, R., Meijer, P.T., 2001. On the dynamics of the Juan de Fuca plate. Earth Planet Sci. Lett. 189, 115-131. https://doi.org/10.1016/S0012-821X(01)00360-0.

Groeber, P., 1918. Edad y extensión de las estructuras de la cordillera entre San Juan y Nahuel-Huapí. Physis, Rev. la Soc. Argentina Ciencias Nat. IV, 208-240.

Grove, T.L., Till, C.B., Krawczynski, M.J., 2012. The role of H 2 O in subduction zone magmatism. Annu. Rev. Earth Planet Sci. 40, 413-439. https://doi.org/10.1146/ annurev-earth-042711-105310.

Grove, T.L., Till, C.B., Lev, E., Chatterjee, N., Médard, E., 2009. Kinematic variables and water transport control the formation and location of arc volcanoes. Nature 459, 694-697. https://doi.org/10.1038/nature08044.

Haller, M.J., Pécskay, Z., Németh, K., Gméling, K., Massaferro, G.I., Meister, C.M., Nullo, F.E., 2009. Preliminary K-Ar geochronology of Neogene back arc volcanism in Northern Patagonia, Argentina. III International Maar Conference IAVCEI, pp. 40-41. Malargüie.

Hawkesworth, C.J., Turner, S.P., McDermott, F., Peate, D.W., van Calsteren, P., 1997. UTh isotopes in arc magmas: implications for element transfer from the subducted crust. Science 276, 551-555. https://doi.org/10.1126/science.276.5312.551.

Henríquez Ascencio, G.J., 2016. Petrografía, geoquímica y marco geotectónico del Complejo Volcánico Ancud, Provincia de Chiloé, Región de los Lagos, Chile. Universidad de Concepción.

Hervé, F., Pankhurst, R.J., Drake, R., Beck, M.E., 1995. Pillow metabasalts in a midTertiary extensional basin adjacent to the Liquiñe-Ofqui fault zone: the Isla Magdalena area, Aysén, Chile. J. South Am. Earth Sci. 8, 33-46. https://doi.org/ 10.1016/0895-9811(94)00039-5.

Iannelli, S.B., Fernandez Paz, L., Litvak, V., Gianni, G., Fennell, L.M., Lucassen, F., Kasemann, S., Oliveros, V., Folguera, A., 2020. Southward-directed subduction of the Farallon-Aluk spreading ridge and its impact on subduction mechanics and Andean arc magmatism: insights from geochemical and seismic tomographic data. Front. Earth Sci. 8 https://doi.org/10.3389/feart.2020.00121.

Iannelli, S.B., Litvak, V.D., Fernández Paz, L., Folguera, A., Ramos, M.E., Ramos, V.A., 2017. Evolution of eocene to Oligocene arc-related volcanism in the north patagonian Andes $\left(39-41^{\circ} \mathrm{S}\right)$, prior to the break-up of the Farallon Plate. Tectonophysics 696-697, 70-87. https://doi.org/10.1016/j.tecto.2016.12.024.

Irvine, T.N.J., Baragar, W.R.A., 1971. A guide to the chemical classification of the common volcanic rocks. Can. J. Earth Sci. 8 (5), 523-548.

Jacques, G., Hoernle, K., Gill, J., Hauff, F., Wehrmann, H., Garbe-Schönberg, D., Lara, L. E., 2013. Across-arc geochemical variations in the Southern Volcanic Zone, Chile (34.5-38.0 S): constraints on mantle wedge and slab input compositions. Geochim. Cosmochim. Acta 123, 218-243.

Jordan, T.E., Burns, W.M., Veiga, R., Pángaro, F., Copeland, P., Kelley, S., Mpodozis, C. 2001. Extension and basin formation in the southern Andes caused by increased convergence rate: a mid-Cenozoic trigger for the Andes. Tectonics 20, 308-324.

Karlstrom, L., Lee, C.A., Manga, M., 2014. The role ofmagmatically driven lithospheric thickening on arc front migration. G-cubed 15, 2655-2675. https://doi.org/ 10.1002/2014GC005355.

Kay, S.M., Ardolino, A.A., Gorring, M.L., Ramos, V.A., 2007. The Somuncura large igneous province in Patagonia : interaction of a transient mantle thermal anomaly with a subducting slab. J. Petrol. 48, 1-35. https://doi.org/10.1093/petrology/ eg1053.

Kay, S.M., Godoy, E., Kurtz, A., 2005. Episodic arc migration, crustal thickening, subduction erosion, and magmatism in the south-central Andes. Geol. Soc. Am. Bull. 117, 67-88. https://doi.org/10.1130/B25431.1.

Kay, S.M., Gorring, M., Ramos, V.A., 2004. Magmatic sources, setting and causes of tertiary to recent patagonian plateau magmatism ( $36^{\circ} \mathrm{S}$ to $52^{\circ} \mathrm{S}$ latitude). Rev. la Asoc. Geológica Argentina 59, 556-568.

Kincaid, C., Griffiths, R.W., 2004. Variability in flow and temperatures within mantle subduction zones. G-cubed 5, 1-20. https://doi.org/10.1029/2003GC000666.

Lara, L., Rodríguez, C., Moreno, H., Pérez de Arce, C., 2001. Geocronología K-Ar y geoquímica del volcanismo plioceno superior-pleistoceno de los Andes del sur (39-42 S). Revista geológica de Chile 28 (1), 67-90.

Lee, C.-T.A., Luffi, P., Plank, T., Dalton, H., Leeman, W.P., 2009. Constraints on the depths and temperatures of basaltic magma generation on Earth and other terrestrial planets using new thermobarometers for mafic magmas. Earth Planet Sci. Lett. 279, 20-33. https://doi.org/10.1016/j.epsl.2008.12.020.
Lizuain, A., 1980. Las formaciones suprapaleozoicas y juásicas de la Cordillera Patagónica. Provincias de Río Negro y Chubut. Asoc. Geol. Argentina, Rev. XXXV, 174-182.

Lizuain, A., Viera, R.M., 2010. Descripción geológica de la Hoja 4372-I y II, Esquel, provincia de Chubut. Inst. Geol. y Recur. Miner. Serv. Geológico Min. Argentino. Boletín 369, 1-92.

Lonsdale, P., 2005. Creation of the Cocos and Nazca plates by fission of the Farallon Plate. Tectonophysics 404, 237-264. https://doi.org/10.1016/j.tecto.2005.05.011.

Lopez-Escobar, L., Kilian, R., Kempton, P.D., Tagiri, M., 1993. Petrography and geochemistry of quaternary rocks from the southern volcanic zone of the Andes between $41^{\circ} 30^{\prime}$ and $46^{\circ} 00^{\prime}$ 's, Chile. Rev. Geol. Chile 20, 33-55.

Lopez-Escobar, L., Parada, M.A., Moreno, H., Frey, F.A., Hickey-Vargas, R.L., 1992. A contribution to the petrogenesis of Osomo and Calbuco volcanoes, Southern Andes (41 $00^{\circ}-41^{\circ} 30^{\prime}$ S): comparative study. Andean Geol. 19 (2), 211-226.

López-Escobar, L., Vergara, M., 1997. Eocene-miocene longitudinal depression and quaternary volcanism in the southern Andes, Chile (33-42.5 ${ }^{\circ}$ ): a geochemical comparison. Rev. Geol. Chile 24, 227-244.

Mahlburg Kay, S., Mpodozis, C., 2002. Magmatism as a probe to the Neogene shallowing of the Nazca plate beneath the modern Chilean flat-slabs. J. South Am. Earth Sci. 15, 39-57. https://doi.org/10.1016/S0895-9811(02)00005-6.

Massaferro, G.I., Haller, M.J., D’Orazio, M., Alric, V.I., 2006. Sub-recent volcanism in Northern Patagonia: a tectonomagmatic approach. J. Volcanol. Geoth. Res. 155, 227-243. https://doi.org/10.1016/j.jvolgeores.2006.02.002.

Matthews, K.J., Maloney, K.T., Zahirovic, S., Williams, S.E., Seton, M., Müller, R.D., 2016. Global plate boundary evolution and kinematics since the late Paleozoic. Global Planet. Change 146, 226-250. https://doi.org/10.1016/j. gloplacha.2016.10.002.

Mazzoni, M.M., Kawashita, K., Harrison, S., Aragón, E., 1991. Edades radimétricas eocenas, borde Occidental de Macizo Norpatagónico. Rev. la Asoc. Geológica Argentina 46, 150-158.

Mella, M., Munoz, J., Vergara, M., Klohn, E., Farmer, L., Stern, C.R., 2005. Petrogenesis of the Pleistocene Tronador Volcanic Group, Andean Southern Volcanic Zone. Andean Geol. 32 (1), 131-154.

Mena, M., Ré, G.H., Haller, M.J., Singer, S.E., Vilas, J.F., 2006. Paleomagnetism of the late Cenozoic basalts from northern Patagonia. Earth Planets Space 58, 1273-1281. https://doi.org/10.1186/BF03352622.

Míková, J., Denková, P., 2007. Modified chromatographic separation scheme for Sr and $\mathrm{Nd}$ isotope analysis in geological silicate samples. J. Geosci. 52, 221-226. https:// doi.org/10.3190/jgeosci.015.

Miyashiro, A., 1974. Volcanic rock series in island arcs and active continental margins. Am. J. Sci. 274, 321-355.

Muñoz, J., Troncoso, R., Duhart, P., Crignola, P., Farmer, L., Stern, C.R., 2000. The relation of the mid-Tertiary coastal magmatic belt in south-central Chile to the late Oligocene increase in plate convergence rate. Rev. Geol. Chile 27, 177-203. https:// doi.org/10.4067/S0716-02082000000200003.

Nakamura, N., 1974. Determination of REE, Ba, Fe, Mg, Na and $\mathrm{K}$ in carbonaceous and ordinary chondrites. Geochem. Cosmochim. Acta 38, 757-775. https://doi.org/ 10.1016/0016-7037(74)90149-5.

Nakayama, C., 1973. Sedimentitas pre-Bayocianas en el extremo austral de la Sierra de Taquetrén, Chubut (Argentina). V Congreso Geológico Argentino, Actas III, pp. 269-277. Villa Carlos Paz.

Navarrete, C., Gianni, G., Encinas, A., Márquez, M., Kamerbeek, Y., Valle, M., Folguera, A., 2019. Triassic to Middle Jurassic geodynamic evolution of southwestern Gondwana: from a large flat-slab to mantle plume suction in a rollback subduction setting. Earth Sci. Rev. 194, 125-159. https://doi.org/10.1016/j. earscirev.2019.05.002.

Nullo, F.E., 1978. Descripción geológica de la hoja 41d, Lipetrén, Provincia de Río Negro: Carta geológico-económica de la República Argentina, escala 1: 200.000. Servicio Geológico Nacional.

Orts, D.L., Folguera, A., Encinas, A., Ramos, M.E., Tobal, J., Ramos, V.A., 2012. Tectonic development of the North Patagonian Andes and their related Miocene foreland basin (41 ${ }^{\circ} 30^{\prime}-43^{\circ}$ S). Tectonics 31, 1-24. https://doi.org/10.1029/2011TC003084.

Orts, D.L., Folguera, A., Giménez, M., Ruiz, F., Rojas Vera, E.A., Lince Klinger, F., 2015. Cenozoic building and deformational processes in the north patagonian Andes. J. Geodyn. 86, 26-41. https://doi.org/10.1016/j.jog.2015.02.002.

Pankhurst, R.J., Weaver, S.D.D., Hervé, F., Larrondo, P., 1999. Mesozoic-cenozoic evolution of the north patagonian batholith in aysén, southern Chile. J. Geol. Soc. London. 156, 673-694. https://doi.org/10.1144/gsjgs.156.4.0673.

Pearce, J.A., Peate, D.W., 1995. Tectonic implicationsof the composition of volcanic arc magmas. Annu. Rev. Earth Planet Sci. 23, 251-285.

Pécskay, Z., Haller, M.J., Németh, K., 2007. Preliminary K/Ar geochronology of the Crater Basalt volcanic field (CBVF), northern Patagonia. Rev. la Asoc. Geol. Argentina 62, 25-29.

Pin, C., Zalduegui, J.S., 1997. Sequential separation of light rare-earth elements, thorium and uranium by miniaturized extraction chromatography: application to isotopic analyses of silicate rocks. Anal. Chim. Acta 339, 79-89.

Plank, T., Langmuir, C.H., 1998. The chemical composition of subducting sediment and its consequences for the crust and mantle. Chem. Geol. 145, 325-394.

Profeta, L., Ducea, M.N., Chapman, J.B., Paterson, S.R., Gonzales, S.M.H., Kirsch, M., Petrescu, L., DeCelles, P.G., 2015. Quantifying crustal thickness over time in magmatic arcs. Sci. Rep. 5 https://doi.org/10.1038/srep17786.

Ramos, M.E., Folguera, A., Fennell, L., Giménez, M., Litvak, V.D., Dzierma, Y., Ramos, V. A., 2014. Tectonic evolution of the North Patagonian Andes from field and gravity data (39-40 ${ }^{\circ}$ S). J. South Am. Earth Sci. 51, 59-75. https://doi.org/10.1016/j. jsames.2013.12.010. 
Ramos, M.E., Orts, D., Calatayud, F., Pazos, P.J., Folguera, A., Ramos, V., 2011. Estructura, estratigrafía y evolución tectónica de la cuenca de Nirihuauen las nacientes del río Cushamen. Chubut. Rev. la Asoc. Geol. Argentina 68, 210-224.

Ramos, M.E., Tobal, J.E., Sagripanti, L., Folguera, A., Orts, D.L., Giménez, M., Ramos, V. A., 2015. The North Patagonian orogenic front and related foreland evolution during the Miocene, analyzed from synorogenic sedimentation and $\mathrm{U} / \mathrm{Pb}$ dating $\left(\sim 42^{\circ} \mathrm{S}\right)$. J. South Am. Earth Sci. 64, 1-19. https://doi.org/10.1016/j.jsames.2015.08.006.

Ramos, V.A., 1982. Las ingresiones pacíficas del Terciario en el Norte de la Patagonia. III Congreso Geológico Chileno, pp. 262-288. Concepción.

Ramos, V.A., Cristallini, E.O., Pérez, D.J., 2002. The pampean flat-slab of the central Andes. J. South Am. Earth Sci. 15, 59-78. https://doi.org/10.1016/S0895-9811(02) 00006-8.

Rapela, C.W., Dias, G.F., Franzese, J.R., Alonso, G., Benvenuto, A.R., 1991. El Batollto de la Patagonia Central: evidencias de un magmatismo Triasico-Jurasico asociado a fallas transcurrentes. Andean Geol. 18, 121-138.

Rapela, C.W., Pankhurst, R.J., 1996. Monzonite suites: the innermost Cordilleran plutonism of Patagonia. Earth Environ. Sci. Trans. R. Soc. Edinburgh 87, 193-203. https://doi.org/10.1017/S026359330000660X.

Rapela, C.W., Pankhurst, R.J., 1992. The granites of northern Patagonia and the gastre fault system in relation to the break-up of Gondwana. Geol. Soc. Spec. Publ. 68, 209-220. https://doi.org/10.1144/GSL.SP.1992.068.01.13.

Rapela, C.W., Pankhurst, R.J., Fanning, C.M., Herve, F., 2005. Pacific subduction coeval with the Karoo mantle plume : the early Jurassic subcordilleran belt of northwestern Patagonia. Geol. Soc. 217-239. https://doi.org/10.1144/GSL.SP.2005.246.01.07.

Rapela, C.W., Spalletti, L.A., Merodio, J.C., 1983. Evolución magmática y geotectónica de la "Serie Andesítica" andina (Paleoceno-Eoceno) en la cordillera Nordpatagónica. Rev. la Asoc. Geológica Argentina 38, 469-484.

Rapela, C.W., Spalletti, L.A., Merodio, J.C., Aragón, E., 1988. Temporal evolution and spatial variation of early tertiary volcanism in the Patagonian Andes $\left(40^{\circ} \mathrm{S}-42^{\circ} 30\right.$ ' S . J. South Am. Earth Sci. 1, 75-88. https://doi.org/10.1016/0895-9811(88)90017-X.

Rapela, C.W., Spalletti, L.A., Merodio, J.C., Aragón, E., 1984. El vulcanismo paleocenoeoceno de la provincia volcánica andino-patagónica. IX Congreso Geológico Argentino. San Carlos de Bariloche, pp. 189-213.

Ravazzoli, I.A., Sesana, F.L., 1977. Descripción geológica de la hoja 41c, Río Chico, Provincia de Río Negro: Carta geológico-económica de la República Argentina, escala 1: 200.000. República Argentina, Ministerio de Economía, Secretaría de Estado de Minería, Servicio Geológico Nacional.

Remesal, M.B., Salani, F.M., Cerredo, M.E., 2012. Petrología del complejo volcánico Barril Niyeu (Mioceno inferior), Patagonia Argentina. Rev. Mex. Ciencias Geol. 29 $463-477$.

Rodriguez M de la, P., de la, M., 2010. El depocentro marino-continental cenozoico de Cholila. In: Provincia del Chubut. Universidad de Buenos Aires.

Rossel, P., Oliveros, V., Ducea, M.N., Charrier, R., Scaillet, S., Retamal, L., Figueroa, O. 2013. The Early Andean subduction system as an analog to island arcs: evidence from across-arc geochemical variations in northern Chile. Lithos 179, 211-230. https://doi.org/10.1016/j.lithos.2013.08.014.

Schellart, W.P., 2017. Andean mountain building and magmatic arc migration driven by subduction-induced whole mantle flow. Nat. Commun. 8, 1-13. https://doi.org/ 10.1038/s41467-017-01847-z.

Sepúlveda, E.G., 1980. Estudio palinológico de sedimentitas intercaladas en la "Serie Andesitica Andina", cordón oriental del Futalaufquen, Chubut. Parte I: restos de hongos. Rev. la Asoc. Geológica Argentina 35, 248-272.

Sernageomin, 2003. Mapa Geológico de Chile: version Digital, No 4. In: Mineria, S.N.d.G y (Ed.), Publicación Geológica Digital. Santiago, Chile.

Silva, C., 2003. Ambiente geotectónico de erupción y metamorfismo de metabasaltos almohadillados de los Andes Norpatagónicos (42 - 46 S), Chile. Universidad de Chile.

Somoza, R., Ghidella, M.E., 2012. Late Cretaceous to recent plate motions in western South America revisited. Earth Planet. Sci. Lett. 331-332, 152-163. https://doi.org/ 10.1016/j.epsl.2012.03.003.

Sosa Massaro, A.P., 2010. Geología Del Cordón Leleque (Arroyo Lepá). In: Región Sur de la Cuenca de Ñirihuau. Universidad de Buenos Aires.

Staudigel, H., King, S.D., 1992. Ultrafast subduction: the key to slab recycling efficiency and mantle differentiation? Earth Planet Sci. Lett. 109, 517-530. https://doi.org/ 10.1016/0012-821X(92)90111-8.
Stern, R.J., 2002. Subduction zones. Rev. Geophys. 40 https://doi.org/10.1029/ 2001RG000108.

Sun, S.S., McDonough, W.F., 1989. Chemical and isotopic systematics of oceanic basalts: implications for mantle composition and processes. Geol. Soc. Lond. Spec. Public. 42 (1), 313-345.

Syracuse, E.M., Abers, G.A., 2006. Global compilation of variations in slab depth beneath arc volcanoes and implications. G-cubed 7. https://doi.org/10.1029/ 2005 GC001045.

Turner, J.C., 1982. Descripción geológica de la Hoja 44c, Tecka, provincia del Chubut. Serv. Geológico Nac. Boletin 180, 1-92.

Tobal, J.E., Rojas Vera, E., Folguera, A., Ramos, V.A., 2012. Deformación andina en el cordón del Hielo Azul al oeste de El Bolsón: Implicancias en la evolución tectónica de la Cordillera Norpatagónica en Río Negro, Argentina. Andean Geol. 39 (3), 442-463.

Turner, J.C., 1965. Estratigrafía de Aluminé y adyacencias, provincia de Neuquén. Rev. la Asoc. Geológica Argentina 20, 153-184.

Turner, J.C.M., 1973. Descripción geológica de la Hoja 37a-b, Junín de los Andes, provincia del Neuquén. Boletín del Serv. Nac. Min. Geológico138 1-86.

Turner, S.J., Langmuir, C.H., 2015. What processes control the chemical compositions of arc front stratovolcanoes? G-cubed 16, 4178-4208. https://doi.org/10.1002/ 2014 GC005633.

Turner, S.J., Langmuir, C.H., Dungan, M.A., Escrig, S., 2017. The importance of mantle wedge heterogeneity to subduction zone magmatism and the origin of EM1. Earth Planet. Sci. Lett. 472, 216-228.

Turner, S.J., Langmuir, C.H., Turner, S.J., Langmuir, C.H., 2015. The global chemical systematics of arc front stratovolcanoes : evaluating the role of crustal processes Evaluating the role of crustal processes. Earth Planet Sci. Lett. 422, 182-193. https://doi.org/10.1016/j.epsl.2015.03.056.

Uliana, M.A., 1978. Estratigrafía del Terciario. VII Congreso Geológico Argentino, Neuquén, pp. 67-84.

Vergara, M., Morata, D., Hickey-Vargas, R., López-Escobar, L., Beccar, I., LopezEscobar, L., Beccar, I., 1999. Cenozoic tholeiitic volcanism in the colbún area, linares Precordillera, central Chile $\left(35^{\circ} 35^{\prime}-36^{\circ} \mathrm{S}\right)$. Rev. geológica Chile $26,23-41$. https:// doi.org/10.4067/S0716-02081999000100002.

Volkheimer, W., 1964. Estratigrafía de la zona extraandina del departamento de Cushamen (Chubut) entre los paralelos $42^{\circ}$ y los $42^{\circ} 30^{\prime}$ y los meridianos $70^{\circ}$ y $71^{\circ}$. Rev. la Asoc. Geológica Argentina 19, 85-107.

Watt, S.F., Pyle, D.M., Mather, T.A., 2011. Geology, petrology and geochemistry of the dome complex of Huequi volcano, southern Chile. Andean Geol. 38 (2), 335-348.

Whitney, D.L., Evans, B.W., 2010. Abbreviations for names of rock-forming minerals. Am. Mineral. 95, 185-187.

Wilf, P., Cúnego, N.R., Johnson, K.R., Hicks, J.F., Wing, S.L., Obradovich, J.D., 2003. High plant diversity in eocene south America: evidence from Patagonia. Science 84 300, 122-125. https://doi.org/10.1126/science.1080475.

Wilf, P., Labandeira, C.C., Johnson, K.R., Cúneo, N.R., 2005. Richness of plant-insect associations in Eocene Patagonia: a legacy for South American biodiversity. Proc. Natl. Acad. Sci. U.S.A. 102, 8944-8948. https://doi.org/10.1073/pnas.0500516102.

Wilf, P., Singer, B.S., Zamaloa, M.D.C., Johnson, K.R., Rubén Cúneo, N., 2010. Early eocene 40Ar/39Ar age for the Pampa de Jones plant, frog, and insect biota (Huitrera Formation, Neuqu??n Province, Patagonia, Argentina). Ameghiniana 47, 207-216.

Woodhead, J.D., Hergt, J.M., Davidson, J.P., Eggins, S.M., 2001. Hafnium isotope evidence for "conservative" element mobility during subduction zone processes. Earth Planet Sci. Lett. 192, 331-346. https://doi.org/10.1016/S0012-821X(01) 00453-8.

Zaffarana, C., Lagorio, S., Orts, D., Busteros, A., Nieto, D.S., Giacosa, R., Ruiz González, V., Boltshauser, B., Puigdomenech Negre, C., Somoza, R., Haller, M., 2019. First geochemical and geochronological characterization of Late Cretaceous mesosilicic magmatism in Gastre, Northern Patagonia, and its tectonic relation to other coeval volcanic rocks in the region. Geol. Mag. 156, 1285-1294. https://doi. org/10.1017/S0016756818000432.

Zaffarana, C.B., Somoza, R., López de Luchi, M., 2014. The late triassic central patagonian batholith: magma hybridization, 40Ar/39Ar ages and thermobarometry. J. South Am. Earth Sci. 55, 94-122. https://doi.org/10.1016/j.jsames.2014.06.006.

Zartman, R.E., Doe, B.R., 1981. Plumbotectonics - the model. Tectonophysics 75 (1-2), 135-162. 